\title{
The role of the error correction journal on the written performance of foreign language students
}

\author{
Budimka Uskokovic Tenney
}

Follow this and additional works at: https://researchrepository.wvu.edu/etd

\section{Recommended Citation}

Uskokovic Tenney, Budimka, "The role of the error correction journal on the written performance of foreign language students" (2014). Graduate Theses, Dissertations, and Problem Reports. 7353.

https://researchrepository.wvu.edu/etd/7353

This Thesis is protected by copyright and/or related rights. It has been brought to you by the The Research Repository @ WVU with permission from the rights-holder(s). You are free to use this Thesis in any way that is permitted by the copyright and related rights legislation that applies to your use. For other uses you must obtain permission from the rights-holder(s) directly, unless additional rights are indicated by a Creative Commons license in the record and/ or on the work itself. This Thesis has been accepted for inclusion in WVU Graduate Theses, Dissertations, and Problem Reports collection by an authorized administrator of The Research Repository @ WVU. For more information, please contact researchrepository@mail.wvu.edu. 


\title{
The Role of the Error Correction Journal on the Written Performance of Foreign Language Students
}

\author{
Budimka Uskokovic Tenney \\ Thesis submitted \\ to the Eberly College of Arts and Sciences \\ at West Virginia University \\ in partial fulfillment of the requirements for the degree of \\ Master of Arts in \\ World Languages, Literatures, and Linguistics \\ Cynthia Chalupa, Ph.D., Chair \\ Johan Seynnaeve, Ph.D. \\ Xiangying Jiang, Ph.D.
}

Department of World Languages, Literatures \& Linguistics

Morgantown, West Virginia

2014

Keywords: error correction, writing, corrective feedback

Copyright 2013 Budimka Uskokovic Tenney 
All rights reserved

INFORMATION TO ALL USERS

The quality of this reproduction is dependent upon the quality of the copy submitted.

In the unlikely event that the author did not send a complete manuscript and there are missing pages, these will be noted. Also, if material had to be removed, a note will indicate the deletion.

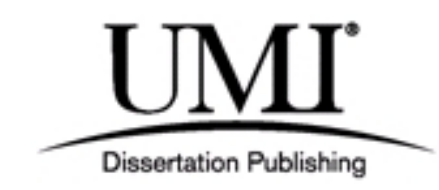

UMI 1554875

Published by ProQuest LLC (2014). Copyright in the Dissertation held by the Author.

Microform Edition () ProQuest LLC.

All rights reserved. This work is protected against unauthorized copying under Title 17, United States Code

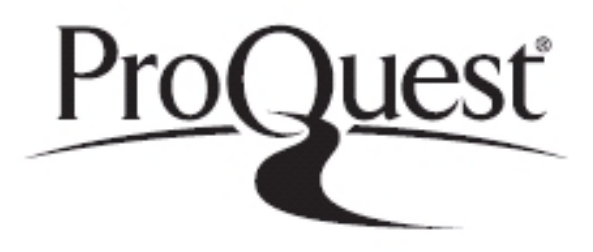

ProQuest LLC.

789 East Eisenhower Parkway

P.O. Box 1346

Ann Arbor, MI 48106 - 1346 


\section{Abstract \\ The Role of the Error Correction Journal on the Written Performance of Foreign Language Students}

\section{Budimka Uskokovic Tenney}

This study focuses on the effects of error recording and analysis in the form of an Error Correction Journal (ECJ) on the linguistic accuracy of students of German and on their motivation to learn the language. It focuses on three groups of students, one that completed the ECJ, one that received coded feedback, and one that was given direct correction. The goal of the study was to check for improved accuracy and increased motivation based on the use of a journal to analyze and to raise awareness about errors. Through the use of the ECJ, students became more aware of their language learning and were better able to recognize and avoid errors. They also became more aware of the types of errors they made and felt more motivated and empowered in their learning based on the use of ECJ. Students in the Experimental Group initially completed a survey in which they rated their greatest areas of weakness. The participants in all groups wrote an initial essay in order to see what types of errors they usually make. They were then asked to write three essays during the course of the semester (two drafts of each) on which they focused on error correction. After submitting and receiving each draft, which was corrected with a correction key, students in the Experimental Group analyzed the nature and frequency of their errors in the ECJ by filling out a chart and reflecting on their mistakes. The instructor compiled the data from the error correction chart to draw conclusions about the types of errors students made. A final essay was assigned at the end of the semester to gage overall improvement. The control groups responded to error correction feedback without keeping a journal. The instructor examined the error data both qualitatively and quantitatively to determine if overall improvement occurred during the semester. At the end of the semester, students in the Experimental Group also rated the degree to which the ECJ had helped them to identify errors and avoid them on subsequent assignments. The findings show that the ECJ helped the participants focus on correctness, think about the form, look at different grammatical categories, and correct their mistakes by themselves. Using the ECJ was important because it empowered learners and helped them become more independent. Even if it did not help them correct all of their errors or significantly improve their weaknesses, it taught them to reflect on their learning and take charge of it. This is not only an important academic skill that can be applied to other areas outside of foreign language learning, but it is also a necessary life skill that students can employ beyond the classroom. 
For my loving parents and siblings 


\section{Table of Contents}

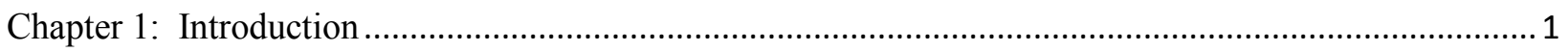

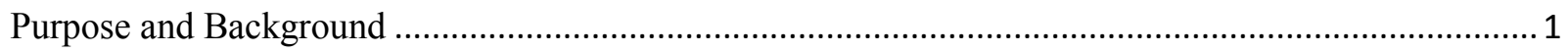

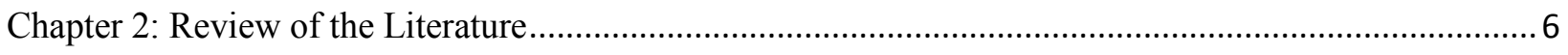

General Overview of Error Correction in Language Learning .................................................... 8

Research on Error Correction and Foreign Language Writing ...................................................... 12

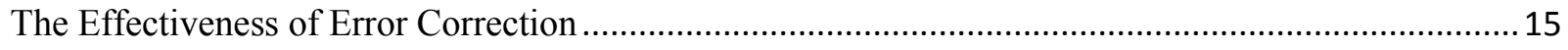

The Ineffectiveness of Error Correction ............................................................................... 18

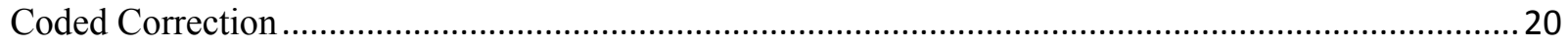

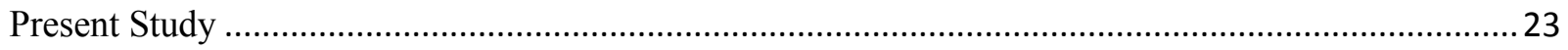

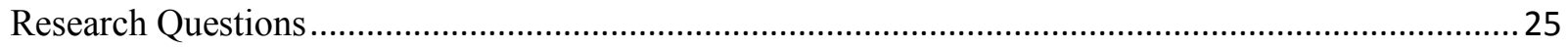

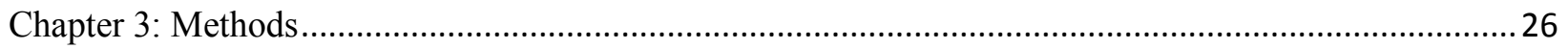

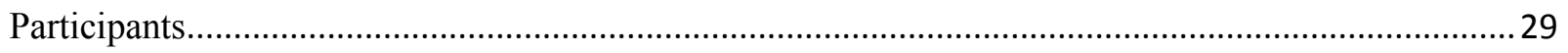

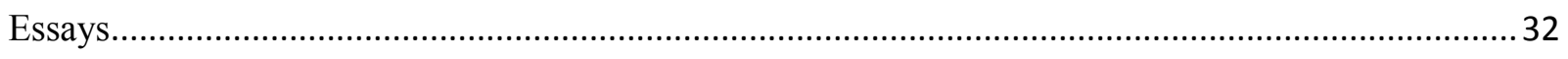

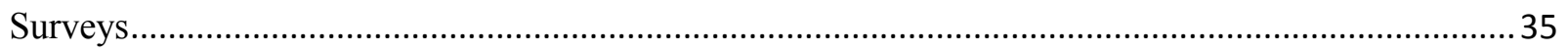

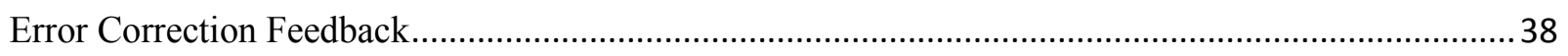

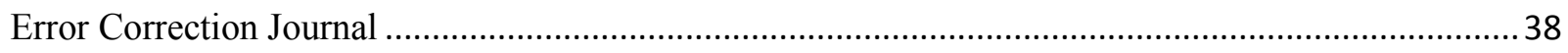

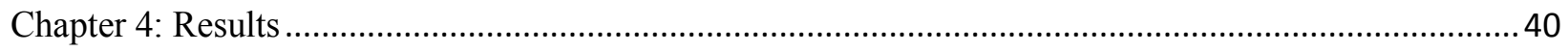

Students' Attitudes toward Errors and Error Correction.................................................................... 40

Advantages of the ECJ in Written Communication ......................................................................... 42

Students' Perception of Their Own Improvement …......................................................................... 46

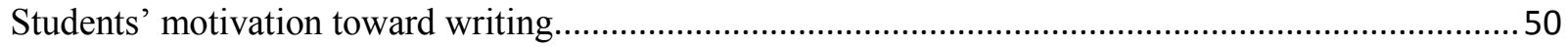

Evaluation of Student Performance Based on the ECJ ….................................................................. 53

Sample of Students' Improvement on All Essays ............................................................................. 58 


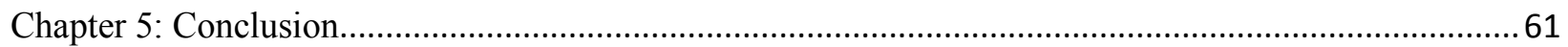

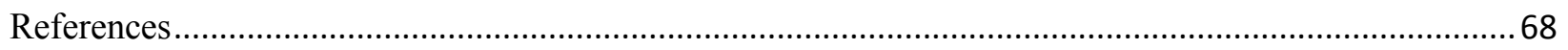

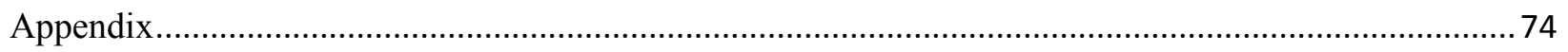

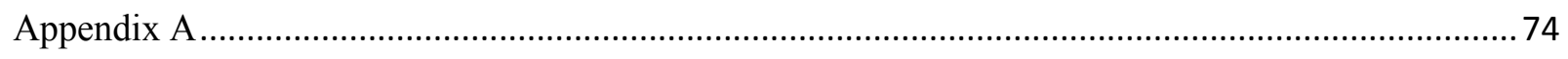

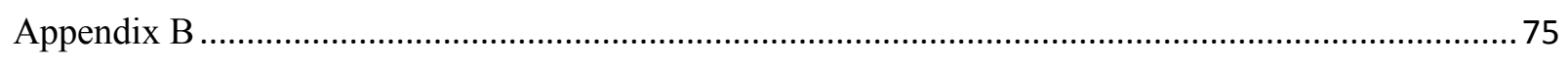

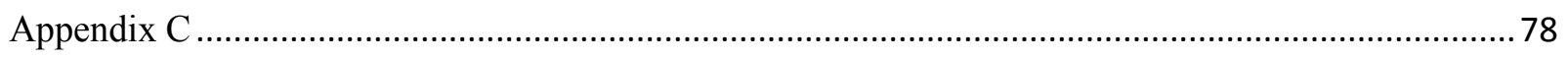

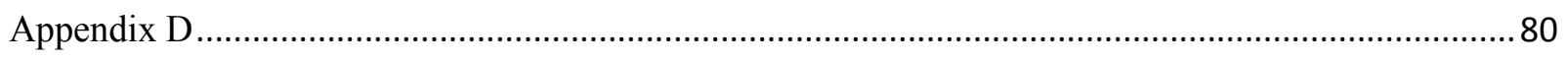

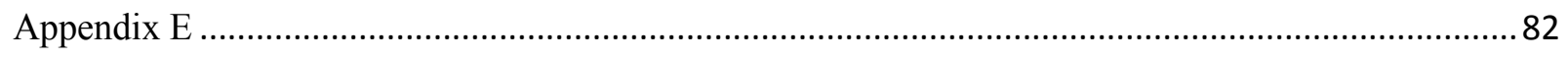




\section{Tables}

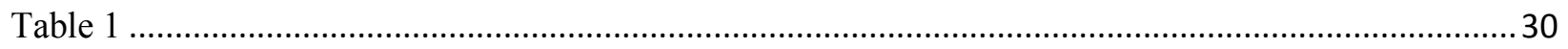

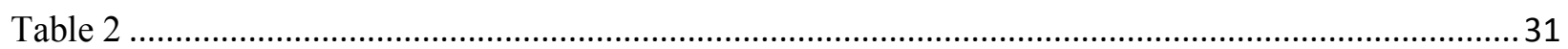

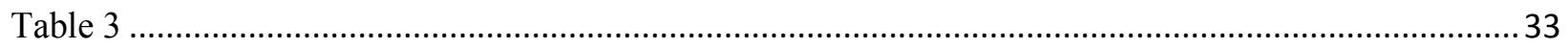

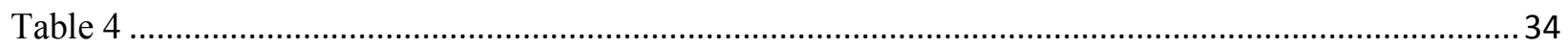

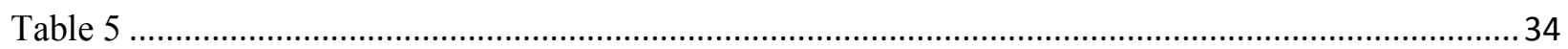

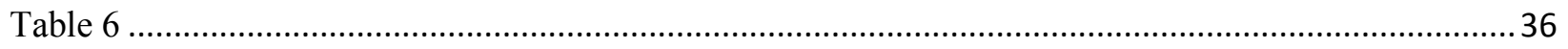

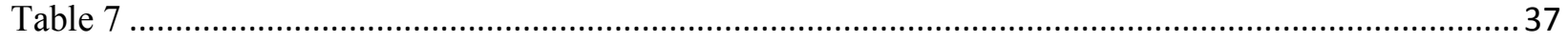

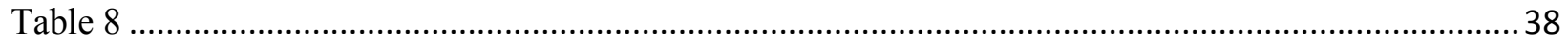

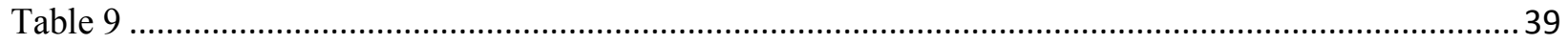

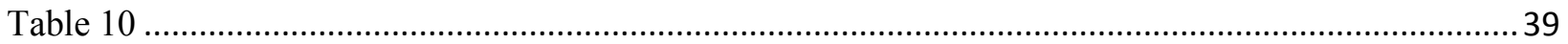

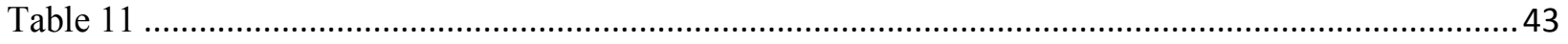

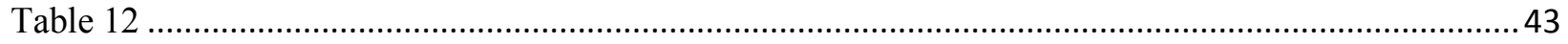

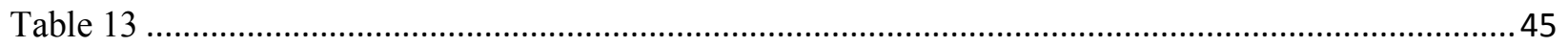

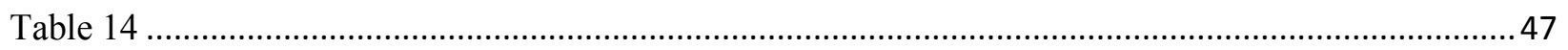

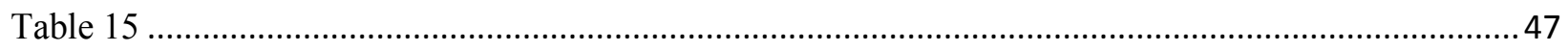

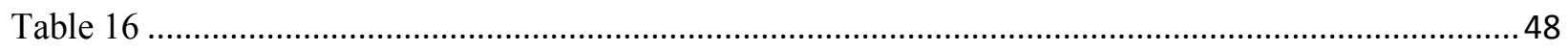

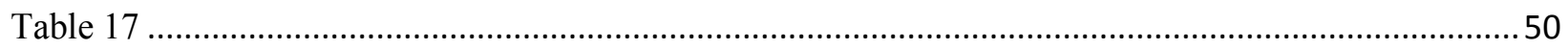

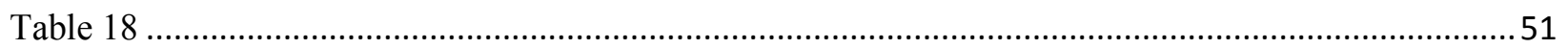

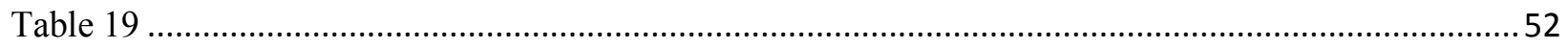

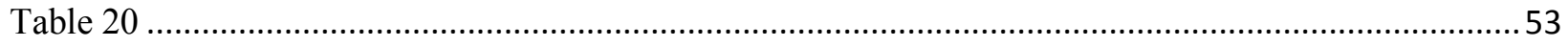

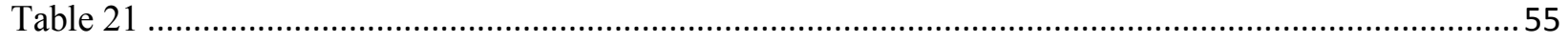

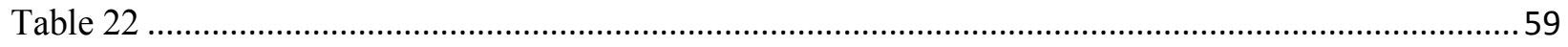




\section{Figures}

Figure 1. Histogram of improvement of the experimental group.

Figure 2. Histogram of improvement of control group II.................................................................. 57

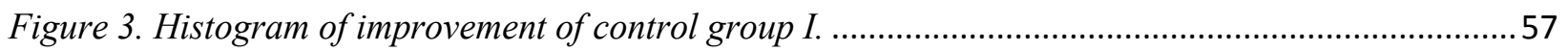




\section{Chapter 1: Introduction}

\section{Purpose and Background}

Research in second language acquisition (SLA) has shown that writing is one of the most important skills for foreign language learners because it reinforces the acquisition of grammar, "a notion that was typically underscored in traditional research studies examining the acquisition of grammatical rules and the development of accuracy" (Homstad \& Thorson, 1994, p.6). Greenia (1992) claimed that this argument was wrong, claiming that "writing in the foreign language in itself has not proved an effective vehicle for learning grammar" (p. 33). In his article, he provides a list of guidelines that focus on writing in the foreign language curriculum, explaining that intermediate or advanced-level writing classes usually do not concentrate on writing; they are either topics courses (focusing on literature) or grammar courses. Brooks and Grundy also reject second language writing as a mode for learning grammatical accuracy and stressed, instead, its discursive power, stating that it should "combine communicative practice, an integrated approach and humanistic principles" (Brookes \& Grundy, 1990). Researchers who are critical of foreign language (FL) writing as a form of grammar instruction ultimately have a more holistic view of writing and underscore that students should have the freedom to express themselves, and that instructors should value their self-expression as intelligent and respect individual learning styles.

Not only is the efficacy of writing for the development of grammatical accuracy debated; also the best way to teach writing remains a point of discussion. There are many varying arguments suggesting how best to go about the teaching of FL writing effectively (Ellis, 2006). Ellis (2009) suggests several guidelines that incorporate corrective feedback, such as ascertaining students' attitudes toward corrective feedback (CF), not being afraid to correct students' mistakes because 
CF really works, using focused $\mathrm{CF}$, ensuring that learners know they are being corrected, and implementing a variety of CF strategies. Ellis also stresses the importance of adapting strategies to the learners being corrected. The instructor should experiment with the timing of CF, attend to the correction and revision of writing, pay attention to the cognitive and affective needs of the individual learner, correct a specific error several times, and monitor the extent to which $\mathrm{CF}$ causes anxiety in learners (Ellis, 2009, p. 14).

One theory suggests that CF from the instructor or another expert interlocutor is most effective in teaching FL writing (Ferris, 2006). Ferris attributes this to the fact that teachers know how to scaffold learning and how to correct students' mistakes without making students anxious. Ferris (1999) argues that more research must be done on the use of CF until feedback is conclusively proved ineffective or detrimental to the learner's learning process. Moreover, Lyster, Lightbrown, and Spada (1999) argue that CF can be integrated in ways that do not interrupt the flow of interaction between the learner and the interlocutor, and therefore suggest that it can be a constructive method of teaching writing. Other researchers argue, however, that the correction provided by teachers may not be the most effective manner in which to draw students' attention to their errors (Truscott, 1996). He rejects any grammatical CF, claiming that it is ineffective and sometimes harmful because it may interrupt communicative activities (p. 330). If teachers focus only on students' mistakes in writing, they do not let them express their opinions, and ignore the message that students want to send, which ultimately may lead to a loss in motivation. Therefore, Truscott suggests that teachers should avoid or completely abandon CF. He bases his rejection on his review of research articles (e.g., Kepner, 1991; Robb et al., 
1986; Semke, 1984; Sheppard, 1992) and claims that CF can be more disruptive than constructive.

Perhaps, the question of whether or not error correction is an effective method of teaching FL writing leads back to students' reaction to having their errors corrected. It is not clear if all students react positively to teacher suggestions and if motivation is positively affected by direct alterations of their work. Many experimental studies on written CF carried out over the last ten years suggest that written corrective feedback can be helpful to students, but studies remain inconclusive as to which type of error correction is most effective and whether all students benefit in the same way from a particular correction method. Further research studies need to examine contextual differences and the issue of individual learning differences among students. In response to the gaps in research on error correction in L2 learning, this study focuses on contextual and learner differences and whether there is a significant difference in the effect of direct versus indirect written corrective feedback on the short-term acquisition of targeted errors, long-term accuracy in writing, and learner motivation.

Questions concerning the approach to error correction in FL writing and its link to student performance and motivation are particularly important for intermediate language students, whose writing has moved beyond the expression of basic vocabulary and learned phrases and is beginning to take on markers of more complex sentence structure, the expression of more complicated ideas, and the markers of different aspects and time frames. At this stage of language learning, students run the risk of making more errors because they are producing more language, albeit in a highly unpolished state. At this level, if students' work is not evaluated productively, with targeted points for improvement, the overall effect of writing assignments can 
be detrimental to their creative expression and motivation to write in the foreign language or continue studying the language.

These issues became particularly apparent to me in the study of third-semester German students at West Virginia University, who wrote multiple essays in order to improve their presentational writing skills, based on which they were evaluated. As a result, I chose to conduct a study in which I examined the effect on writing and motivation of error correction journaling done by students in contrast to the results that direct correction feedback given by the instructor have on student performance. My main objectives in this study were to: 1) identify the most frequent errors; 2) devise a method by which to help students recognize those errors themselves; and 3) propose ways in which students can be motivated to correct their errors based on a higher awareness of the types of mistakes they make. Among the most common errors were lexical, grammatical, syntactic and semantic inaccuracies, each with a different origin and reason according to the individual learner. Based on the results of this study, I hoped to develop research-based directives for helping students to understand the origin of their errors and the errors that they most frequently make so that they may avoid them in the future.

This thesis consists of five chapters with the following headings: Review of the Literature, Methods, Results, and Conclusion. Following the current chapter, in which I introduce the topic of the thesis and the reasoning behind the research project, I present, in Chapter 2, the most significant research studies about CF. I also provide an historical overview of the language theories that have affected practices of error correction in writing and summarize the most important results that impact the present study. Based on the review of literature on CF 
in writing, I demonstrate how the current study fits into a larger corpus of research on the issue of error correction in writing, and present the research questions.

In Chapter 3, I present the current study in more detail, explaining the research questions, the selection of participants, the methods of data collection, tasks for the participants, and the purpose of this study in the field of research on error correction and FL writing. For this study, I utilized a combination of qualitative and quantitative methods in order to gain an indepth understanding of students' mistakes, their awareness of errors, and the reasons that govern them. In order to lend credibility and dependability to the qualitative study, I combine qualitative methods with quantitative data analysis, which provides a more objective view of student performance. Stating the importance of coded feedback, I also show why I focused on indirect feedback rather than on direct feedback in the Experimental Group, which wrote three essays using the Error Correction Journal (ECJ) and which answered the initial and final survey about the nature and the frequency of their errors, and provide the reasoning for my focus on grammar structures rather than on style, content or vocabulary.

In Chapter 4, I present the qualitative data in conjunction with quantitative results. The qualitative data, which I examine in the first part of the chapter, is based on answers in the surveys and student comments written after each draft. These comments show students' general attitudes toward errors and error correction, their views of the advantages of the Error Correction Journal and of their own improvement, and students' motivation toward writing. In the second part of the results, I focus on grammatical accuracy and students' average scores from the first draft of each essay so I can see if they have improved from the previous essay after a month and if they are still motivated to write. 
In Chapter 5, I examine further ramifications of the results and place the current study in the context of previous research studies. Moreover, I discuss the limitations of this study and directions for future research on the topic of error correction. Finally, I discuss the practical application of the research results and their impact on classroom teaching and discuss ways in which students can be empowered through the use of the Error Correction Journal.

\section{Chapter 2: Review of the Literature}

The acquisition of strong writing skills is paramount to the learning of a foreign language, but research shows that many debates still exist about the best way to teach them. What follows is an examination of current research in the field of error correction as it applies to FL writing. Through the examination of previous research on the teaching of FL writing and the use of error correction in doing so, I set the context for the current study on error correction and the importance of the Error Correction Journal.

To begin, it is useful to examine the definition of an error as it applies to FL learning. According to Lennon (1991, p. 182), an error is a "linguistic form or combination of forms which, in the same context, and under similar conditions of production would, in all likelihood, not be produced by the native speakers' counterparts." Moreover, Stern (1992) states that errors are an integral part of language learning. Correcting errors is one of the most challenging and difficult parts of FL acquisition and written accuracy can be improved only if experts help students avoid errors in the future. According to Harmer (2009), there are two distinct sources for the errors that most students make: developmental errors and errors caused by L1 interference. If we take German as an example, the difference in these types of errors becomes clearer. As we will see in this study, most intermediate students of German in the United States 
at WVU make errors at the level of gender, case, adjective endings, word order, and sentence structure. Mistakes in gender, case, and adjective endings can be considered developmental errors because students do not have these categories in their L1 if they are native speakers of English. On the other hand, the latter two categories, word order and sentence structure errors, are based on L1 interference because the word order and sentence structure of English is less dependent on case and more dependent on the placement of words than German.

Ultimately it is clear that error correction can help students improve their ability to write accurately, as the review of literature below will show, and it is an important part of the language-learning process for both teachers and students. Writing teachers believe that responding to student errors is a vital part of their job (Ferris, 1995), and students are eager for teachers' feedback on their writing and believe that they benefit from it (Leki, 1991; Radecki \& Swales, 1988). In fact, error correction is important to the classroom and learning atmosphere because 1) it facilitates writing development of intermediate level students (Ferris, 1995); and 2) it produces results if a revision phase is built into the instructional cycle (Hedgock \& Lefkowitz, 1996, p. 145).

The review of literature that follows highlights the most important studies in the field of error correction in FL teaching and learning. It is ordered according to the following categories: 1) general overview of error correction in learning; 2) previous research theories in languagespecific environment; 3) the effectiveness of error correction; 4) the ineffectiveness of error correction; 5) coded correction; and 6) the present study. 


\section{General Overview of Error Correction in Language Learning}

Theories of writing and error correction have developed accordingly with the establishment of the various theories of second language acquisition. These theories encompass a wide variety of approaches, from the behaviorist method, in which the learner makes active and repeated responses to stimuli (Skinner, 1957), to proficiency-based teaching approaches common today. Many researchers argued that in early years, writing was only emphasized as a means to practice the vocabulary and grammar that had been learned, and errors were not tolerated (Brown, 2007; Ferris \& Hedgock, 2005; Matsuda, 2006; Silva, 1990, as cited in Ferris, 2010, p. 182-183). The audio-lingual approach, which was driven by behavioral psychology in the early decades of the twentieth century, used as its basis publicly observable responses that could be analyzed and adjusted for accuracy. Writing, in this regard, was an excellent vehicle for the demonstration of accuracy and could clearly show evidence in learning (or the absence of it) based on the correct application of rules and paradigms. Although behaviorist approaches to language acquisition emphasized spoken communication, it underscored the accuracy and the notion that language mastery was achieved through repetition and the utterance of correct responses.

According to behaviorist theories of language learning, incorrect responses were “punished” based on Skinner's psychological theories of reinforcement and punishment (Skinner, 1957). Language researchers based their concept of error correction on the manner in which children acquire their first language. When children attempt to make words based on what they hear, they are rewarded for their babblings by receiving the item they asked for or their responses are reinforced through the correct utterance of the word they were trying to say. Based on this reinforcement, they are motivated to produce further articulations and to expand them into 
syllables and words. The audio-lingual method was characterized by a similar approach to error correction in a formal setting. It focused on the production of perfect output through multiple repetitions and immediate and direct error correction. In school settings, teachers corrected mistakes immediately without accounting for negative consequences on the learners. Teachers placed emphasis on repetition rather than meaning and required learners to repeat until the form was correct even if they did not understand what they were saying.

Noam Chomsky (1959), one of the first language theorists who changed the way that native language acquisition was viewed, criticized the behaviorist theory, using his universal grammar model to explain how children learn their first language. In this model, Chomsky argues that learners are able to create new sentences, which they have never learned before, based on the "language acquisition device (LAD)" (Chomsky, 1965, p. 25). The LAD enables them to process language, and it contains abstract principles of language that are universal to all languages. When learners hear language, this activates the LAD and triggers internal rules specific for the language they hear. The learner learns through internalizing language rules, rather than by producing repeated responses to stimuli (Ellis, 2008). The LAD concept explains errors as the result of the learner thinking through the process of rule formation. In this stage of second language acquisition research, some linguists and psychologists noted that oral or written errors were part of "a necessary stage of the developmental process, similar to what children go through as they acquire a first language" (Corder, 1967; Krashen, 1982, as cited in Ferris, 2010, p. 183). One of the reasons for this more natural view of errors was based on the concepts of competence and performance. Chomsky viewed competence as the intuitive knowledge of rules of grammar and syntax and of how the linguistic system of a language operates. Performance, 
on the other hand, is seen as individual's ability to produce language. In this view, language production results from the creative application of a learned set of linguistic rules. Only through adequate exposure to a language and the opportunity to express their language creatively without interruption and punishment can a learner improve in language production, making acquisition possible.

Subsequent research was greatly influenced by Lev Vygotsky, a child psychologist and educational researcher working at the beginning of the twentieth century. His sociocultural model of the zone of proximal development (ZPD) was not originally applied to language learning but is very applicable to SLA. For him, social interaction was the fundament of cognitive development because only through interaction with an expert could the learner progress. According to Vygotsky, the learner has two levels of development: actual and potential developmental level. The actual developmental level represents what the learner can do without assistance, whereas the potential developmental level represents what the learner can do with the assistance of a more advanced interlocutor. Between those two levels is the learner's ZPD which Vygotsky defined as "the distance between the actual developmental level as determined by independent problem solving and the level of potential development as determined through problem solving under adults guidance or in collaboration with more capable peers" (Vygotsky, 1934/1978, p. 86). For him, error correction served as a means of scaffolding that helped guide the learner through the ZPD. Only through feedback from the expert and from practice can learners move from "other-regulation" provided by the teacher to self-regulation and the development of greater independent control over the material they are trying to learn. "The schoolchild, though growing steadily in awareness and mastery of such functions as memory and 
attention, is not aware of his conceptual operations. All the basic functions become 'intellectual' except the intelligence itself' (Vygotsky, 1986, p. 167).

The use of error correction in FL writing was also influenced by Krashen's Monitor Model and his Order Hypothesis (Krashen, 1982, 1984; Krashen \& Terrell, 1983, as cited in Ferris, 2010, p. 185). In particular, Krashen's Monitor Model provides an important framework for examining students' errors and their awareness of them. The Monitor Model refers to the conscious knowledge of rules that prompts the internal "monitor" to check, edit, and polish language output, but it issued only when the language learner has sufficient time, understands the linguistic form, and knows the rule being applied (Krashen, 1982, p.19). The Order Hypothesis, on the other hand, defines how learners acquire the rules of a language in a predictable sequence, no matter how effective the teaching methods are. Therefore, for Krashen error correction may have little or no effect on the acquisition process because the language acquisition occurs naturally, and students will be able to correct their mistakes only when they have attained an advanced level of acquisition.

Another important theory on the treatment of errors in SLA is Selinker's Interlanguage (IL) Theory and Processes, which define how learners make and test hypotheses about the target language and readjust their mental model of the new language (Selinker, 1984). He came up with processes, such as simplification (e.g., the use of very little speech to produce a message), overgeneralization (e.g., the use of L2 rules in places where they are not applicable), restructuring (e.g., the use of the first language to reorganize grammar knowledge), and fossilization (e.g., the permanent lack of mastery). All of these processes are important for understanding error correction because in Selinker's view, errors are seen as evidence of positive 
efforts by the learner to learn a new language. Selinker attests that transfer of forms plays a role in IL construction as a strategy employed by learners (Brown, 2000). It is good to experiment with the language and make mistakes because that is one of the ways the IL can develop. Moreover, if communication is successful, then transfer will or may happen. The danger is that successful communication does not depend entirely on formal correction. Selinker is also aware that correction cannot occur only in the classroom, but a lack of correction can lead to fossilization because of persistent errors that have not been corrected on time.

\section{Research on Error Correction and Foreign Language Writing}

Recent research in SLA theory and foreign language pedagogy still suggests that the question regarding the efficacy of error correction has not been conclusively determined. Nevertheless numerous studies have suggested that error correction plays an important role in the acquisition of a foreign language. What follows is an overview of studies showing the link between error correction and the acquisition of language in a foreign language setting. Nassaji and Swain (2000) have done a case study with two female Korean learners of English who were learning to write in English as a second language. The study was conducted in Canada within a five-week intensive intermediate writing class. The goal of the study was to examine the importance of a ZPD error treatment procedure. One participant got indirect feedback at the beginning; the researchers simply read but did not correct errors. After that, the participant got more help in a gradual and progressive fashion, while the other participant got random feedback. The results show that the participant who received error correction within the ZPD improved over time although she performed less accurately in the use of article on the first essay. The student receiving random feedback did not show a similar degree of progress, which suggests 
that direct and explicit feedback is more efficacious and enables students to collaborate, interact, and communicate their errors.

The most directly relevant study to the issue of error correction is Aljaafreh and Lantolf (1994). In their study, three university students of ESL met once a week with a tutor over the course of eight weeks. Instead of providing direct error correction for the students to look at, the tutors used a series of prompts designed to allow the student to first self-correct the error. If the student did not self-correct, the tutors gradually added help, for example, by pointing to the location of the error and then noting the type of error. Aljaafreh and Lantolf showed changes over time in the amount of independence the learner had acquired in correcting an error, until the use of the structure became automatic, or in sociocultural terms, self-regulated.

Another study of error correction in the form of reformulation was completed by Brooks and Swain (2009). In this study, students participated in four tasks. First, a pair of students wrote a story collaboratively and second, compared it to a reformulated version. This second session was recorded for the third step, which was a variation on a stimulated recall in which the researcher viewed the session with the participants answering questions and scaffolding was provided by an interlocutor. Finally, the students were asked to revise the original essay without seeing the reformulations. Brooks and Swain noted that the participants used different experts to help them revise their work: their peer, the reformulation, and the researcher. The results showed that depending on the difficulty of the language in relation to the developmental level of the students, these sources varied in terms of how successful they were in helping the learners solve a linguistic problem. 
In contrast to studies underscoring the importance of error correction, another body of research questions the ability of error correction methods to improve student performance. Most research studies examine the difference between direct (errors are corrected) and indirect (errors are identified, but not corrected) forms of feedback (Chandler, 2003; Ferris and Roberts, 2001; Lalande, 1982; Robb et al., 1986). Others focused feedback on content and feedback on form (Fathman \& Whalley, 1990), which combined both feedbacks, but some compared different types of feedback longitudinally (Chandler, 2003; Lalande, 1982; Robb et al., 1986). There are several approaches to delivering error correction. Some researchers focused on feedback given between drafts (Ashwell, 2000). Others focused on error rates compared between first and last papers in a 10-week term (Chandler, 2003), or first and last papers of term (Ferris, 2006), and written CF on first drafts followed by in-class editing on same paper (Ferris \& Roberts, 2001). Depending on the type of feedback and short- and long-term correction, in different studies students have shown significant improvement based on feedback. Errors were corrected in several ways, (e.g. they were coded, circled, underlined, underlined and coded, underlined with a description of the error, and counted in the margin), or they were neither marked nor coded. ${ }^{1}$

In addition to different methodologies in error correction research, there are also different results in the analyses of the effectiveness of error correction. These results lay on a continuum that rates error correction effective or ineffective, valid or invalid, and beneficial or harmful. Therefore, there are three approaches to understanding the efficacy of error correction: error correction is effective; error correction is not effective; coded correction provides a compromise.

\footnotetext{
${ }^{1}$ For the purposes of this study, the terms error correction and error feedback are considered to be synonymous.
} 


\section{The Effectiveness of Error Correction}

There are several studies that show the effectiveness of error correction. Falhasiri et al. (2011) pointed out that students must be aware of their mistakes in order to have more success in long-term learning. In this study, 23 male and female undergraduate students from different majors were asked to write four compositions on predetermined topics for four weeks. Their errors were analyzed based on a linguistic Category Taxonomy which was developed by Burt and Kisparsky into which they classified several English errors made by students learning English as well as host environments (interlingual errors, misuse of preposition, using double subject in relative clauses, etc.), and the frequency of errors for each category was calculated (p.254). Two types of feedback were used: explicit explanation of interlingual errors (their time always is free) and implicit clarification of intralingual errors (a electricity). After that, students wrote four more compositions, and the frequencies between two sets of writing were compared. It was found that the most errors were of an interlingual nature $(71 \%)$, and the frequency of mistakes in 22 out of 26 categories decreased because of error correction. Explicit correction of interlingual and implicit teaching of intralingual errors also decreased the frequency of mistakes made by the students.

The results of the research study conducted by Bitchener and Knoch (2009) show similar results. They conducted a study in the English Language Department in Auckland, New Zealand. There were two structures chosen for the study: the referential indefinite article and the referential definite article, and there were four different groups. Group One received direct error correction as well as written and oral meta-linguistic explanation. Group Two received direct error correction and written meta-linguistic explanation. Group Three received only direct error 
correction, and Group Four did not receive corrective feedback at all. The groups that received written CF were more successful than the group that did not receive any feedback at all, even when writing a new text seven weeks after the treatment session and the immediate post-test. They bettered their performance in accuracy using the targeted functions of the English article system (the referential indefinite article 'a' for referring to something the first time and the referential article 'the' for referring to something that has been mentioned before), and they retained the same level of accuracy when writing a new text. The authors also noted that the differences in the three different written corrective options in the post-tests were not found to be statistically significant.

This study is unique in that the researchers focused on only one grammatical category (articles) and three different treatment approaches. It also supports Truscott's (1996) prediction that written CF may be effective for helping learners acquire some linguistic forms (p. 495). The researchers show that a single written CF treatment is effective in helping learners improve the accuracy of their writing and that the benefits acquired from this input are evident not only over time, but also in new pieces of writing. Further research studies focusing on this level of accuracy over a more extensive period would provide helpful information on the effect of this type of feedback on student performance.

Some researchers have investigated whether more in-depth meta-linguistic comments (providing learners with some form of explicit comment about the nature of the errors they have made) might be a more effective form of error correction. Sheen (2007) has examined the use of such comments in the improvement of students' performance. Other researchers have looked at the efficacy of reformulations (repetitions of what the learner has said in a correct form without 
drawing attention explicitly to the error itself) and think-aloud-strategies (Polio \& Sachs, 2007) and noted that they have had a significant effect on student learning. Sheen (2007) examined 91 participants with different first languages in three different treatments: a direct-only correction group, a direct metalinguistic correction group, and a control group. The researchers found that experimental groups performed better than the control group, but the direct metalinguistic group performed better than the direct-only correction group in the delayed posttests. A significantly positive association between students' gains and their aptitude for language analysis was also found. Moreover, their aptitude for linguistic analysis was more strongly linked to acquisition in the direct metalinguistic group than in the direct-only group. All participants improved their accuracy in the use of articles.

Polio and Sachs (2007) examined the effectiveness of written error correction versus reformulations of FL learners' writing as two means of improving learners' grammatical accuracy on a three-stage composition-comparison-revision task. Fifteen adults participated in a repeated-measures study with three experimental conditions: error correction, reformulation, and reformulation with think-aloud. All participants had to write a 30-min picture description. The participants in the first experimental condition had to look at written error corrections of the story for 15 minutes on the next day. After that, they revised a clean copy of the original story without access to the corrections. The participants in the second experimental condition had to compare the story to a reformulated version for 15 minutes, and then to revise a clean copy of the original story without access to the reformulation. The participants in the third experimental condition had to compare the story to a reformulated version while thinking aloud. After that, they had to revise a clean copy of the original story without access to the reformulation. The 
results of this research study showed that reformulatons were not more efficacious than error correction but they produced better results than reformulation with think-aloud. In fact, there are no significant differences between groups receiving different types of feedback.

All of the above researchers concluded that metalinguistic comments were very helpful (Sheen, 2007; Polio \& Sachs, 2007), but in a research study conducted by Ellis, Loewen, and Erlam (2006) metalinguistic comments were significant only in the delayed oral imitation and grammaticality judgments posttests. The participants in this study were divided into three groups. The first group received implicit feedback (recast), the second group received explicit feedback (metalinguistic comments), and the third group didn't receive any type of feedback. The relative effectiveness of both types of feedback was assessed on an oral elicited imitation test, a grammaticality judgment test, and a test of metalinguistic knowledge. The target grammatical structure was past tense $-e d$. The participants had pretests and posttests. The posttests were completed the day after the second (and last) day of instruction, and 12 days later. The researchers found out that learners have to locate the error, to be able to distinguish dissimilarities between forms, and to decide what grammatical category causes problems.

\section{The Ineffectiveness of Error Correction}

Although many recent research studies demonstrate the effectiveness of error correction, one must also note the most important studies that show the ineffectiveness of error correction. These studies were conducted by Kepner (1991), Truscott (1996) and Truscott and Hsu (2008), and all of them inspired subsequent research studies.

Kepner (1991) experimented with 60 Spanish FL students at U.S. university. Half of the participants received comprehensive correction on sentence-level errors with a brief explanation 
or statements of rules; the other half received comments on content instead. Kepner discovered that college students who received surface-level error correction did not make significantly fewer errors in their journals (only 15\%) than those who received message-related comments. He proved this point by checking the sixth assignment written after 12 weeks of instruction. The results are skewed by the fact, however, that students in the study were not required to do anything with the teacher's corrections. All participants were learning Spanish but were not majors, there was no pretest measure of errors or propositional content in the students' journal entries, and there was no control for the length of journal entries. It is therefore unclear to what degree they actually processed the feedback.

Other studies have likewise suggested that error correction is not always integral to student improvement in FL writing. Chandler (2003) discovered "that if students did not revise their writing based on feedback about errors, having teachers mark errors was equivalent to giving no error feedback" (p. 288). This was demonstrated by the fact that students' scores and accuracy in writing did not improve over the semester. Truscott (1996) likewise suggests that written feedback can be ineffective in student learning or even have a detrimental effect. He explains that learning is most successful when students are relaxed and confident and enjoying their learning, and that the use of correction leads to a rise in anxiety and less enjoyment of the learning process, and by extension, their motivation to learn. Even students who believe that correction is a necessary part of learning, “... do not enjoy the sight of red ink all over their writing and find the experience extremely discouraging" (p. 354). 


\section{Coded Correction}

Coded correction seems to provide a compromise between the effectiveness and ineffectiveness of other types of correction explained above. The most significant theory that supports coded correction can be found in the notion of "input enhancement" (Smith, 1991), which refers to "corrective feedback as one specific form of consciousness raising" (Fotos, 1993, p. 386), or "noticing" (Schmidt, 1990, p. 129). In order to learn any aspect of the L2, students have to notice the relevant linguistic structures. One important characteristic of "noticing" is that as forms become intake and learners produce these with increasingly greater ease, they become routine for the learner (Smith, 1991).

These research studies suggest that it is important to draw students' attention to their errors and to encourage them to explore on their own the source of them. All learners have some kind of universal set of errors, which includes simplification, generalization including L1 transfer, imitation, as well as a set of operating procedures, which includes the use of formal rules, use of repairs, rote memorization, and talk/listen variation. Their attention needs to be drawn to these typical errors even while the teacher helps them to develop strategies for recognizing the individual errors that they make. Some studies show that discovering solutions may be more motivating for learners than simply copying forms provided by teachers (Lalande, 1982, p. 147; Edge, 1989, p. 53).

In Lalande’s study (1982), 60 learners of German were divided into a control group, which was provided with correct forms of errors made in essays and asked to re-write the work accordingly. Members of the experimental group received coded feedback, rewrote their work, and kept an error log. After five essays, Lalande found that only $23 \%$ of the control group was 
making fewer mistakes, while $63 \%$ of the experimental group had decreased their error frequencies. Coded feedback and log-keeping of errors, he claims, had led to lower overall error frequencies.

Greenslade and Félix-Brasdefer (2006) conducted a study with 19 students of Spanish as a foreign language, who were divided into intermediate and advanced levels of proficiency. The data were collected in two classroom sessions during which participants were asked to write two narrative compositions. In the first composition, syntactic, lexical, and mechanical errors were indicated by underlining, and in the second, errors were underlined and then coded. The researchers concluded that coded corrective feedback is much better than merely underlined errors because it helps students to self-correct on the second draft. It is possible that the researchers came to this conclusion because they included not only grammar errors, but also lexical errors in their study. By contrast, Ferris and Roberts (2001) focused only on grammar errors and pointed out the importance of accuracy and therefore error correction in students' writings and the students' willingness to receive feedback on their errors. They compared three different feedback conditions: a) errors marked with codes from different error categories, b) errors underlined but not otherwise marked or labeled, and c) no feedback. The major findings were that the type of error feedback did not significantly aid participants in correcting their errors on the second draft of their compositions, but that the experimental groups outperformed the control group with no feedback.

Summing up, Guénette (2007) pointed out that further research should include different types of research design to address the variety of issues in error correction and to control as many variables as possible. In scrutinizing the research methodology, she points out that 
efficacy of feedback may be attributable to proficiency levels, which is a variable that is rarely measured and reported accurately. Also, while there is already a deficit in the amount of research that uses both a control group and experimental group; those few that do usually fail to keep all other variables consistent. Some of the variables that teachers usually ignore include classroom contexts (e.g., Are the control group and experimental group receiving the same instruction? Does their instruction place attention on the principle of focus on form?). Student incentive also presents a challenge in gathering accurate data (e.g., Are students being graded on the way they react to the feedback?). A third factor that is often overlooked but intricately related to improvement based on error correction is motivation. If students are not motivated to improve, error correction, in any form, is likely to be ineffective.

From these studies, one can conclude that students are able to pay attention to the existence of new features in L2 based on error correction. They are able to pay attention to the existence of new features, but they cannot effectively predict where they will make errors, and they often do not recognize the errors they have made without guidance from an expert. Error correction is therefore imperative in notifying learners of their limitations; in this regard, error correction is a "noticing facilitator" (Schmidt, 1995, p. 27). As we can see from previous research, the results regarding the efficacy of error correction on FL writing are still inconclusive. By reviewing such studies, it can be inferred that further research is needed to investigate the importance of students' recognition of errors and their subsequent avoidance of them in written communication. Future studies should examine how students can improve their writing based on the keeping of a journal in which they record the frequency of their errors and provide comments on those errors. These research studies should also focus on the relationship 
between students' motivation and error correction in order to determine which types of feedback are helpful without deterring students' desire to learn or work creatively with language.

\section{Present Study}

The present study seeks to address the gap in the literature by examining students' grammar errors, their awareness of those errors, their improvement over the course of the semester based on a comparison of errors over time, and the overall changes in their motivation to learn based on the error correction process. By doing so, the present study will contribute to existing research by providing more evidence on students' awareness, their recognition of errors, their motivation, and the accuracy of their work. The study takes grammatical accuracy rather than content as its focus because it is an important aspect of communicative competence, and accuracy can be measured both quantitatively and qualitatively. Writers, who are better able to address the needs and expectations of their readers, in part by drawing on formal or grammatical conventions, are more successful communicators. Moreover, error correction is also a focus-onform instrument (Ellis, 2005; Van Beuningen, 2010). According to Long (1991, p. 46), the focus-on form approach “overtly draws students' attention to linguistic elements as they arise incidentally in lessons whose overriding focus is on meaning or communication." As a result, FL students will pay attention to linguistic features as necessitated by communicative demand.

This study also has practical ramifications for the classroom in its examination of the usefulness of an Error Correction Journal (ECJ). The ECJ used for this study (Appendix A) has a number of components designed to help students recognize the nature of their errors and to explore the reasons for those errors. It consists of charts (Appendix A) in which students log their errors in a variety of grammar categories (verbs, subject-object agreement, gender, article, 
case, plural, adjective ending, pronouns, negation, prepositions, word order, conjunctions, sentence structure). It also includes questions about students' awareness of their errors and their satisfaction with the error feedback. The main goals of the ECJ are to track students' mistakes, to help them understand the frequency and the nature of the most common mistakes they make, to make predictions and conclusions about students' development, and also to determine in what ways students can become more aware of their mistakes and avoid them on each subsequent assignment.

The aim of this study is to determine the effects that journaling about errors can help students improve their writing and motivation for learning. The study is based on the premise that when students have a higher awareness of their most frequent errors they are better able to avoid them in the future. The idea that students can improve their linguistic competence through a higher awareness of their production in the language is not new. In the 1970s, language awareness (LA) was put forward, primarily by modern linguists, as a new 'bridging' element in the UK school curriculum. For instance, Carter (as cited in Andres, 2007)) states that the "awareness involves at least ... a greater self-consciousness about the forms of the language we use. We need to recognize that the relations between the forms and meanings of a language are sometimes arbitrary, but that language is a system and that is for the most part systematically patterned" (p.12).

Language awareness (LA) is a mental attribute which develops through paying motivated attention to language in use and enables language learners to gradually gain insights into how languages work (Barjesteh \& Vaseghi, 2012, p. 1). Hernandez (2011) concluded that raising students' awareness of their mistakes helped them develop their writing skills in a more 
interesting, relaxed, and effective way, for example, by exchanging email messages to ask for and receive feedback. In her study, she found that having students share the errors they frequently make with their classmates raises awareness of their mistakes. As the above research shows, it is not enough for students to correct their errors based on comments from the teacher. They need to understand the source of their errors, talk about them, and take an active role in the correction process in order to avoid making the same mistakes in the future.

\section{Research Questions}

In order to examine the effect of heightened awareness on writing performance, this study focused on the link between student awareness and the frequency and nature of errors. The study was progressive in nature, examining whether or not students' overall writing performance improved based on the development of awareness throughout the course of the semester. In order to gain an understanding of the link between awareness, error correction, and improvements in writing, the present study employed the ECJ, which provided both quantitative and qualitative data to offer insights into the following research questions:

1. Can an ECJ improve the ability of students to avoid common errors in written communication?

2. Do students perceive an improvement when they use an ECJ as a learning tool?

3. Do students perceive improved motivation toward writing?

These questions were designed with the objective of helping students self-correct and thereby improve their overall writing. The first research question examines the ways in which the recording of and reflection on errors can help students avoid the same errors in the future. In order to answer this question, participants were asked to fill out a chart with the number and 
types of errors they commonly made after receiving drafts of their essays with teacher feedback. Students were asked to focus on particular types of errors, such as gender, case, and verb tense on each draft of all three essays.

The second research question examined whether students found that the reflective process involved with the ECJ helped them improve their writing by avoiding mistakes in subsequent writing samples. In order to answer the second research question, students were asked to respond to a number of items, which are described in more detail below. The third question examined the ways in which reflective process initiated by the composition of an ECJ improved students' motivation to write and to continue learning the language in general. Because students were not given pre- or post-tests to gage their grammatical accuracy, the above research questions focus more on students' perception of error correction and motivation rather than on their linguistic performance alone. In the discussion of the results in Chapter 4, however, student improvement was quantified in an effort to draw correlations between error correction and heightened grammatical accuracy.

\section{Chapter 3: Methods}

As shown in the above review of the literature much work still needs to be done in raising students' awareness of the nature and number of errors that they make and how this can best be done. In this chapter, I explain the structure of data collection employed in order to analyze the errors students make and examine the effect that journaling about these errors can have on student learning.

There were three groups in this study: an Experimental and two Control groups. At the beginning, students in the Experimental Group completed a survey (Appendix B) in which they 
rated the areas in which they make the most errors. All groups also wrote an initial essay in order to see what types of errors they usually make; for this essay they received a grade, which was later compared with other writing samples. They were asked to write three essays during the course of the semester (two drafts of each) for which they utilized error correction procedures. After submitting and receiving the first draft, which was corrected with a correction key (Appendix C), students in Experimental Group analyzed the nature and frequency of their errors in the ECJ by filling out a chart provided by the instructor (Appendix A). The instructor compiled the data from the error correction chart to draw conclusions about the types of errors students make. A final essay was assigned at the end of the semester to gage overall improvement. The control groups responded to error correction feedback without keeping a journal. Control Group I received direct feedback, and Control Group II received the same coded feedback as Experimental Group, but they did not keep a journal about their errors. The essays were collected, and the errors were analyzed and compared in order to see if students made the same mistakes after they received their first essay with suggested correction, or if there was a significant difference in improvement between Experimental Group, Control Group II, and Control Group I. The data were analyzed quantitatively and qualitatively, and the instructor checked for overall improvement during the course of semester. At the end of the semester, all students completed the survey again and reevaluated their areas of weakness (Appendix D). Students in the Experimental Group also rated the degree to which the ECJ helped them to identify and avoid errors on subsequent assignments. The findings also provide important insights into learning processes, such as the effect of increased awareness on the motivation to learn outside of the classroom. 
In order to collect information about individual learners' reaction to error correction, students were asked to write a series of three essays, with two drafts each, about which they received feedback. Essays were a part of the syllabus for the courses in which the study was conducted. They were a part of a three-pronged assessment model called Integrated Performance Assessments (IPAs), a testing form promoted by the American Council on the Teaching of Foreign Languages. The IPA model consists of an interpretive segment (comprehension of a written or listening text), an interpersonal segment (short written or spoken exchanges), and a presentational segment (prepared writing or speech). The presentational segment is designed to evaluate students' writing on a theme that is addressed in both the interpretive and interpersonal IPAs. Students complete the first draft of their essay in class and are allowed to use a (3"x5") note card with vocabulary and other learning tips but without English translations, conjugation tables (e.g. adjective endings), conjugated verbs (e.g. simple past forms), full sentences and sentence fragments, or tiny handwriting/printouts. For this study, some students received feedback on their essays in the form of direct correction of mistakes without additional feedback (Control Group I), while the other students were asked to participate in a reflective process of error correction, which involved the active identification of writing challenges through journaling and surveys (Experimental Group).

The Error Correction Journal (ECJ), through which the above reflective activities took place, were designed as a tool to provide students with a deeper insight into their errors through the completion of charts and written reflection on their errors. Students were asked to identify common errors, reflect on what helped them improve their writing, and to discuss their attitudes toward errors and the manner in which they were corrected. Ultimately, the answers they 
provided in the written segments of the ECJ revealed important insights into their ability to selfcorrect errors through reflection and the effects that this process had on their motivation to continue writing.

\section{Participants}

This study was conducted at West Virginia University, a public land grant university in Morgantown, WV during the spring semester of 2013. The location of the study was limited to one university based on its physical location and accessibility. Enrollment for the spring 2013 semester was 29,707 for the main campus, while enrollment across all campuses totaled 32,593. There are 15 colleges and schools offering 197 bachelor's, master's, doctoral, and professional degree programs in agriculture, natural resources, and design; arts and sciences; business and economics; creative arts; dentistry; education and human services; engineering and mineral resources; journalism; law; medicine; nursing; pharmacy; physical activity and sport sciences; and public health. This broad range of academic disciplines was represented in the majors of participants in the study because most students are to take a foreign language as a major or college requirement.

The study was conducted in a world languages department, which offers classes in ten different languages. The introductory and intermediate language sequence, which consists of two courses at each level, is taught by graduate teaching assistants. The author of this study was teaching and conducting research while teaching the third course in the series, an intermediatelevel course, called German 203. German 203 is an intermediate German course designed to help students develop their basic interpretive, interpersonal, and presentational communication 
skills through practice in speaking, listening comprehension, reading, writing, and cultural awareness activities. The main objectives of the course are presented in the table below:

Table 1

Objectives of the course

Upon completion of this course, students will be able to:

analyze and summarize more complex texts

demonstrate an understanding of German linguistic structures, vocabulary items and idiomatic expressions

identify and describe German products, practices, and perspectives

communicate through writing essays, participating in role-plays, and engaging in class discussions

There were 36 undergraduate students (11 women and 25 men) with different majors (only 2 were German majors) taking the course for 17 weeks, from January till May 2013. All of them were U.S.-Americans with English as their first language who had some previous knowledge in German based on their previous education at the high-school and/or college level. The participants were randomly divided in two control groups, and one experimental group. There were two control groups with two different error correction treatments in order to see the effectiveness of indirect vs. direct feedback. Control Group I received direct feedback, which means that all errors were corrected and the participants were asked to use the corrections directly in the second draft of their essays. Control Group II received coded feedback, which required each participant to use a correction key (Appendix C) and self-correct their errors based on hints given by the teacher. Other students volunteered to be participants in the Experimental Group, which used the ECJ to reflect on their errors prior to rewriting their essays.

This study features multiple data collection techniques taken from a large body of research methods that feature aspects of a mixed methods research approach. Both quantitative and qualitative research data were collected and analyzed. The mixed methods approach was 
used in order to gain a better understanding of the research problem since it provides multiple viewpoints of the research problem. The data collection techniques employed in the present study are outlined and discussed further in the next section.

\section{Data Collection Methods}

The study is based on a collection of different forms of data (initial survey, a pre-test initial essay, two drafts of three course essays, the error correction journal, a post-test final essay, and a final survey) used to investigate the extent to which students' writing can improve based on the employment of the ECJ as a learning tool. The data collection process is outlined in Table 2, which shows the timeline of the study and how the study was conducted in all three groups.

Table 2

Timeline

\begin{tabular}{|c|c|c|c|c|c|c|c|c|}
\hline & $1 / 18 / 2013$ & $2 / 6 / 2013$ & $2 / 15 / 2013$ & $3 / 6 / 2013$ & $3 / 15 / 2013$ & $4 / 15 / 2013$ & $4 / 22 / 2013$ & $5 / 8 / 2013$ \\
\hline $\begin{array}{l}\text { Control } \\
\text { Group I }\end{array}$ & $\begin{array}{l}\text { Initial } \\
\text { Essay }\end{array}$ & $\begin{array}{l}\text { First } \\
\text { Draft } \\
\text { (direct) }\end{array}$ & $\begin{array}{l}\text { Second } \\
\text { draft } \\
\text { (direct) }\end{array}$ & $\begin{array}{l}\text { First } \\
\text { Draft } \\
\text { (direct) }\end{array}$ & $\begin{array}{l}\text { Second } \\
\text { Draft } \\
\text { (direct) }\end{array}$ & $\begin{array}{l}\text { First } \\
\text { Draft } \\
\text { (direct) }\end{array}$ & $\begin{array}{l}\text { Second } \\
\text { Draft } \\
\text { (direct) }\end{array}$ & $\begin{array}{l}\text { Final } \\
\text { Essay }\end{array}$ \\
\hline $\begin{array}{l}\text { Control } \\
\text { Group II }\end{array}$ & $\begin{array}{l}\text { Initial } \\
\text { Essay }\end{array}$ & $\begin{array}{l}\text { First } \\
\text { Draft } \\
\text { (coded) }\end{array}$ & $\begin{array}{l}\text { Second } \\
\text { Draft } \\
\text { (direct) }\end{array}$ & $\begin{array}{l}\text { First } \\
\text { Draft } \\
\text { (coded) }\end{array}$ & $\begin{array}{l}\text { Second } \\
\text { Draft } \\
\text { (direct) }\end{array}$ & $\begin{array}{l}\text { First } \\
\text { Draft } \\
\text { (coded) }\end{array}$ & $\begin{array}{l}\text { Second } \\
\text { Draft } \\
\text { (direct) }\end{array}$ & $\begin{array}{l}\text { Final } \\
\text { Essay }\end{array}$ \\
\hline $\begin{array}{l}\text { Experimental } \\
\text { Group }\end{array}$ & $\begin{array}{l}\text { Initial } \\
\text { Essay + } \\
\text { Survey }\end{array}$ & $\begin{array}{l}\text { First } \\
\text { Draft } \\
\text { (coded + } \\
\text { ECJ) }\end{array}$ & $\begin{array}{l}\text { Second } \\
\text { Draft } \\
\text { (direct } \\
+\mathrm{ECJ})\end{array}$ & $\begin{array}{l}\text { First } \\
\text { Draft } \\
\text { (coded + } \\
\text { ECJ) } \\
\end{array}$ & $\begin{array}{l}\text { Second } \\
\text { Draft } \\
\text { (direct + } \\
\text { ECJ) }\end{array}$ & $\begin{array}{l}\text { First } \\
\text { Draft } \\
\text { (coded } \\
+ \text { ECJ) } \\
\end{array}$ & $\begin{array}{l}\text { Second } \\
\text { Draft } \\
\text { (direct + } \\
\text { ECJ) }\end{array}$ & $\begin{array}{l}\text { Final } \\
\text { Essay + } \\
\text { Survey }\end{array}$ \\
\hline
\end{tabular}

At the beginning of the research study, all participants were asked to write a pre-test initial essay. At the same time, the participants in the Experimental Group volunteered to participate in the study by signing a letter of agreement and completed a survey. All participants also wrote three different essays with two drafts of each, but they received a different type of feedback. Only 
Control Group II and the Experimental Group had the correction key because they received coded feedback. At the end, all participants wrote a post-test final essay. The Experimental Group filled out a final survey in order to see their perception of the overall improvement throughout the semester.

\section{Essays}

Students wrote a total of five essays (initial pre-test essay, three IPA essays, and a final post-test essay). Topics were very similar, and students were supposed to use grammar structures, communicative strategies, and vocabulary items covered in the class. After the initial pre-test essay, all students were expected to write three essays, with two drafts of each, as part of the course requirements. Students were required to write the essay as part of the IPA testing that occurred after each chapter. As shown in the literature review (Lalande, 1982; Ashwell, 2000; Chandler, 2003; Ferris \& Roberts, 2001; Ferris, 2006), the draft system is very useful to test a deep, comprehensive reflection on errors, to examine their improvement and ability to selfcorrect mistakes if provided with the indirect feedback, and to gage the students' capability of learning from mistakes if provided with direct feedback. In order to test the reflection process and improvement, the participants in the Experimental Group had to count their errors, comment on their mistakes on both drafts which were parts of the ECJ (charts and surveys).

The first essay was written on February 6, 2013, during the fourth week of the semester. The students received and were asked to respond to the following prompt: 
Table 3

Prompt for the First Essay

You are a trainee in a travel agency in Germany and you should write a paragraph in 80 words for a travel guide for Germans about your favorite city in the U.S. How big is the city? What do you know about the history of the city? What sightseeing possibilities are there? What can you do in the city (sport, museums, activities, etc.)? What else can you do there? Think about malls, restaurants, boat rides, etc. Be creative!

All students had 30 minutes to finish all of their written assignment in class and to turn it in. They were expected to write 80 words, a requirement for each of the essays. After that, the researcher corrected all mistakes using the correction key adapted by R. Minert (Appendix C).

The first draft was evaluated using the IPA Presentational Rubric (Appendix E) and returned to the students. This rubric consists of several components, such as communication of task (adequacy of response to task; effectiveness of communication, content, expression culturally accurate), language control (correct use of appropriate grammatical forms, register, and tense), content/vocabulary (use of new or relevant vocabulary; creative approach to material; involvement of all speakers), and creativity/sentence variation (experimentation with and variation of sentence structure; attempts to demonstrate varied word order and more complex sentence structure including conjunctions and front fields). After that, they had to use the correction key to improve their errors and type the second draft. On February $15^{\text {th }}$, students turned in the second draft, which was used to determine improvement from the first draft. Students in the Experimental Group were also evaluated in terms of their ability to use the key to correct mistakes and revise the first draft. The grades of both drafts were averaged together for an overall grade on the Presentational IPA. 
The topic of the second essay, written on March $6^{\text {th }}$, during the eighth week of the semester, was more creative in nature and required the use of the simple past tense. The prompt for the second essay is below (Table 4).

Table 4

Prompt for the Second Essay

You are certainly familiar with various fairy tales from your childhood, e.g., Little Red Riding Hood. Now you can write your own fairy tale. Write a story in 80 words about heroes, witches, princesses, etc. What happened and when? Use the Past Simple Tense (Imperfekt)!

Students went through the same correction process as above and turned in the second draft on March $15^{\text {th }}$. The topic of the third topic was to describe life in 10 years plans using the future tense. Students wrote the first draft of the third essay on April $15^{\text {th }}$, during the fourteenth week of the semester and turned in the second draft on April $22^{\text {nd }}$. The prompt for the third essay is below (Table 5):

Table 5

Prompt for the Third Essay

Write an essay in 80 words about your life in 10 years after your graduation. Use the Future Tense! Think about kind of profession, what duties and responsibilities you will have, if you would like to work outdoors or indoors, weather you will work with a new technology and/or animals, describe job atmosphere.

On May $8^{\text {th }}$, students took the final exam, and the essay on the final exam was used as a post-test essay to determine students' writing development throughout the semester. The topic of the final essay was to describe summer break plans in 80 words using the future tense.

Control Group I received direct feedback only on the first draft. The participants received the right form of their mistake, and were asked to rewrite the first draft by using the 
right forms which were provided by the teacher. They received an average grade of both drafts. At the end of the semester, the participants wrote the post-test final essay.

Control Group II received coded feedback on the first draft. The participants had to use the correction key in order to correct their mistakes. They received an average grade of both drafts. At the end of the semester, they wrote the post-test final essay.

The Experimental Group received coded feedback. The participants had to use the correction key in order to correct their mistakes, but they also had to reflect on their mistakes filling out the chart, and answering questions about the first and second draft. Both drafts of the Experimental Group were compared, and the teacher also examined the number of mistakes and comments made by the Experimental Group in their ECJ. At the end of the research study, students in the Experimental Group had to fill out a survey presenting their progress and areas they have improved, and areas they still make mistakes.

\section{Surveys}

As shown in the Table 2, there were two surveys given only to the Experimental Group; one at the beginning (initial survey, see Appendix B), and one at the end of the semester (final survey, see Appendix D). Surveys were chosen as an effective data collection method because they are easy to develop and administer, and they allow the researcher to ask numerous questions of and about participants. This provides extensive flexibility in data analysis; however, there were also some disadvantages posed by the survey as a data collection method. These issues, which will be discussed closely in the data analysis below, include the fact that participants might not have been fully aware of the reasoning behind their answers (e.g. because of lack of memory on the subject or even boredom). 
In order to provide rich quantitative and qualitative analyses, survey questions were organized according to the Likert scale from 0 to 5 (with 0 being low and 5 being high). The questions were both open-ended and closed-ended. Closed-ended questions may have had a lower validity because the participants were forced to give simple answers to complex questions. Because they were quick and easy to answer, however, they were also easier to code, analyze statistically, and compare. The open-ended questions, on the other hand, permitted an unlimited number of answers, and the participants could answer in rich detail. These closed-open questions were useful for the quantitative collection of data because student responses could be ranked on a scale. .

Students in the Experimental Group were asked the following close-ended questions in order to provide an overview of the general and specific nature and quantity of mistakes that they typically made. The survey questions also provided the researcher with information regarding students' attitudes toward written correction feedback. It is important to emphasize that the initial and final surveys were not a part of ECJ. It was developed in addition to the ECJ, and all close-ended questions are presented in the Table 6.

Table 6

Close-ended Questions on the Initial Survey

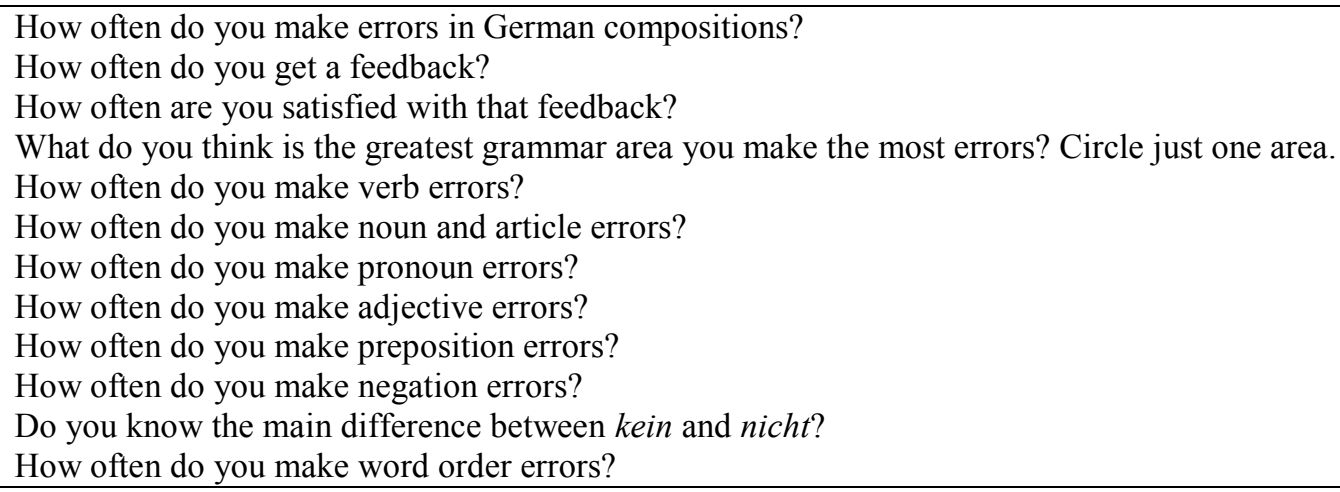


Is the word order in a simple declarative sentence more difficult for you than the word order in the question sentence?

How often do you make coordinating conjunction errors?

How often do you make subordinating conjunction errors?

What do you think is the best way to provide a feedback?

Do you think that an instructor can help students to identify the errors they make in written communication?

Do you think that an Error Correction Journal can improve the ability of students to

recognize and avoid common errors in written communication?

There were 18 questions in the initial survey that students in the Experimental Group completed during the first week of classes. The results of the survey were used to establish a basis of performance in writing for each student and to determine, prior to the completion of the presentational writing tasks, how aware students were of their own mistakes.

The final survey was used after the last essay and was again distributed only to the Experimental Group in order to see to what extent the participants had improved, to what extent the error correction journal had helped them to avoid their mistakes on the second drafts if each of the essays, and whether their attitudes towards written correction feedback had changed. The following set of close-ended questions was used:

Table 7

Close-ended Questions on the Final Survey

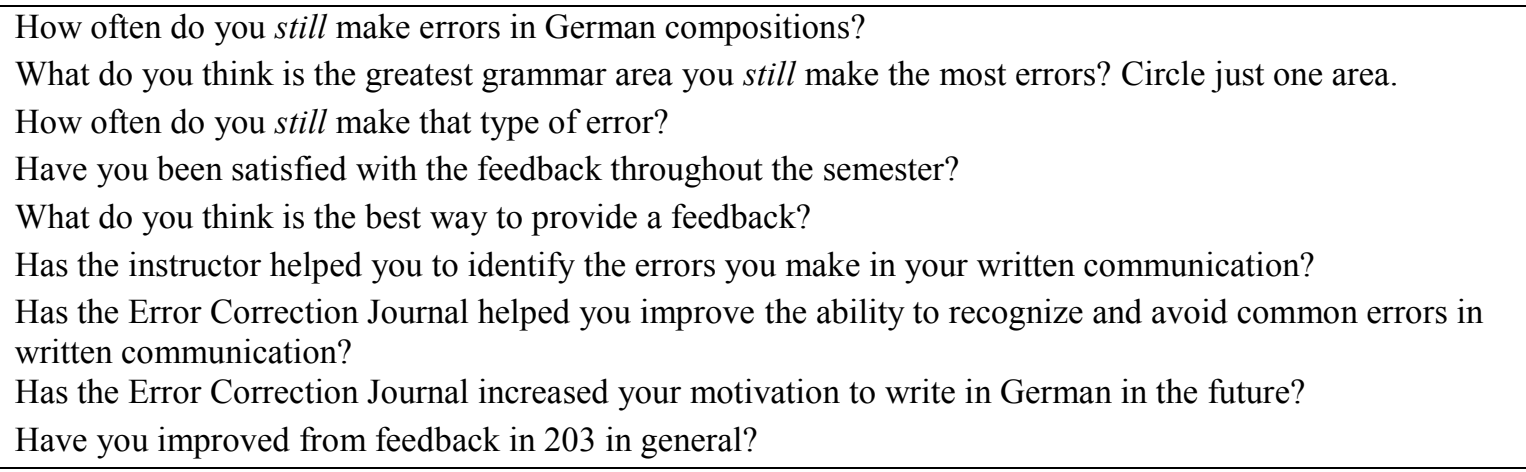

There were ten questions in the final survey, and there were many differences between the format and content of the initial and the final surveys. The initial survey consists of questions 
which should determine students' attitudes and knowledge at the moment, whereas the final survey also focuses on students' actions toward better writing proficiency and the course content.

\section{Error Correction Feedback}

As mentioned above, not all students received the same type of error correction feedback. The participants in Control Group II and the Experimental Group were able to rely on the correction key, whereas the Control Group I got their corrected essay in the following form:

\section{ist}

\section{Meine Lieblingsstadt in den USA is Pittsburgh.}

Examples demonstrating the use of the correction key are provided below.

Table 8

Examples from the Error Correction Key

\begin{tabular}{llll}
\hline AE & Adjektivendung & incorrect adj ending & $\begin{array}{l}\text { ein guter Buch: } \\
\text { ein gutes Buch }\end{array}$ \\
& Konjunktion & wrong conjunction & Wenn ich ein Kind war \\
& & Als ich ein Kind was \\
\hline
\end{tabular}

\section{Error Correction Journal}

The ECJ, which was used by Experimental Group only, consisted of a chart with different grammar structures listed. Students in Experimental Group had to note the number of mistakes they made in each grammar category on both the first and second drafts. The students were 
asked to fill out the chart for each of the drafts in order to draw attention to their mistakes. They were then asked to compare both drafts in order to see if they had improved and to determine if the coded feedback had a positive effect on their recognition of common errors. An example of the error chart is provided in Appendix A. Students in the Experimental Group were asked to answer the following questions after the first draft:

Table 9

Questions about the First Draft

1. What do you think about your errors?

2. Why do you think you made them?

3. Is the way your errors have been corrected appropriate for you?

4. Do you understand now why your constructions have those errors?

5. Do you think that you can benefit if you write the second draft?

6. Do you think that the chart can help you?

7. Do you think you will be able to avoid those mistakes in the future?

8. Can this type of correction feedback motivate you in your future writing?

After the second draft, students were asked to answer the following questions:

Table 10

Questions about the Second Draft

1. Do you think you have improved from the second draft?

2. Do you think that you can avoid those mistakes in the future?

3. How much did the chart help you notice your mistakes?

4. Do you think you will be able to recognize your errors next time you encounter them?

5. Can you tell me something about your motivation for your future writing?

Ultimately, the correction methods used on the essays of different groups and the assignment of different activities surrounding essay writing was intended to isolate the effects of the ECJ on student performance and motivation. By using different correction methods on the essays from each of the groups, the researcher was able to focus on the distinguishing features of the ECJ that positively affected student preparation and performance. The survey questions enabled the researcher to gain a better understanding of student attitudes toward correction and 
its efficacy in improving written performance and the motivation to write. The results of the ECJ analysis and its effect on student motivation and performance will be discussed in greater detail in Chapter 4.

\section{Chapter 4: Results}

This chapter examines the results of the study based on the research questions and discusses the research outcomes in relation to results of previous research studies on error correction and FL writing. The discussion of the results is broken down according to the following categories: 1) students' general attitudes toward errors and error correction; 2) advantages of the ECJ on written communication; 3) students' perception of their improvement; 4) changes in students' motivation toward writing based on the ECJ.

\section{Students' Attitudes toward Errors and Error Correction}

As stated above, the researcher asked students in the Experimental Group to fill out an initial survey (Appendix B) about errors and error correction in order to gain deeper insight into their attitudes toward writing, their areas of difficulty, and their awareness of these areas. According to the first question on the initial survey (How often do you still make errors in German compositions?), students perceived the frequency of their errors as quite high. On the Likert scale (0-5), $45.45 \%$ of the students said they make errors frequently, and $45.45 \%$ noted that they make errors occasionally. Students also described the rate of feedback as high, with $63.6 \%$ noting that they received frequent comments and corrections on their work. The survey also shows students' overall satisfaction with the type of feedback they received, with $54.5 \%$ giving that category the highest rating. In response to Question 4, (What do you think is the 
greatest grammar area you make the most errors?), students listed articles (54.5\%) and prepositions $(27.3 \%)$ as the areas of greatest error-making.

Students were asked to evaluate the frequency of their errors on the Likert scale in a variety of categories, such as verb errors (Q 5), article errors (Q 6), pronoun errors (Q 7), adjective errors (Q 8), preposition errors (Q 9), and negation errors (Q 11). Based on these categories, students provided the following assessment of their rate of errors: verb errors (occasionally - 45.4\%), noun and article errors (occasionally - 45.4\%), pronoun errors (occasionally - 54.5\%), adjective ending errors (occasionally - 45.4\%), preposition errors (occasionally - 36.4\%) and (frequently- 36.4\%), and negation errors (frequently 54.5\%). Students also identified areas in which they made relatively few errors. For example, 63.6\% said they understood the difference between the forms of negation in German: kein and nicht (Q 11). Results show that some students said that they make word order errors only sometimes $(27.3 \%)$, while others describe word order errors as rare (36.4\%). Students noted that they made errors frequently in only two areas. They listed the rate of errors in the use of coordinating and subordinating conjunctions (Q 14 and 15) as frequent (54.5\%), and 27.3\% of the surveyed students said that they made word order errors frequently. Interestingly, one would expect the participants to rank their word order errors much higher since word order in German differs greatly from English. This low rating of word order errors may be attributable to the fact that some of the students were not fully aware of the mistakes they made, or that in the Experimental Group were participants with very good background knowledge and were familiar with the rules of word order. 
The survey results also provide good insights into students' reception of and response to error correction. Most of the students reported a preference for direct feedback (72.7\%) over indirect feedback (27.3\%). All students agreed that an instructor can help students to identify the errors they make in written communication (100\%) and that the Error Correction Journal can improve the ability of students to recognize and avoid common errors in written communication $(100 \%)$. Student ratings reveal that they appreciated additional learning tools. The participants in the Experimental Group also showed their tendency to experiment with new approaches to error correction and a willingness to examine their errors in depth. In this regard, the ECJ was an important tool of which students felt they could make good use.

\section{Advantages of the ECJ in Written Communication}

Students provided feedback on the ECJ based on its component parts: free-response questions after each draft of the essay, a chart with the numerical evaluation of errors in different categories (Appendix A), and essays. What follows is an examination of students' comments, their evaluation of the writing process, and the use of the error correction chart as a learning tool.

As part of the draft-writing process, students in the Experimental Group were asked to answer questions about the nature of the errors they made on the first draft prior to writing the second draft and on the second draft prior to writing a subsequent essay. Students were then asked to evaluate the effectiveness of the ECJ by answering free-response questions about the manner in which the errors were corrected and how those corrections could help them in their future writing. These evaluations of the ECJ were compared with comments about the ECJ and collected after subsequent essays and their drafts had been written. The answers to the questions 
about how the ECJ had helped students were compared for similarities and differences. The questions distributed to students after the completion of the first draft are presented below.

Table 11

Questions about the ECJ after the First Draft

1. Is the way your errors have been corrected appropriate for you?

2. Do you think that you can benefit from writing a second draft?

3. Do you think that the chart of errors helps you?

4. How much did the chart help you notice your mistakes?

5. Do you think you will be able to avoid those mistakes in the future using ECJ?

Responses to the first question show that the students were satisfied with the feedback that they received from the teacher. Moreover, $100 \%$ of the students stated that they believe they can benefit from writing a second draft because repetition is crucial for practice and improvement (Q2). In addition to favorably evaluating the draft-writing process, students also reflected positively on the process of filling out the error correction chart in their answers to Questions 3 \& 4. The comments contained in Table 11 corroborate the students' numerical ratings of the chart and its effect on error recognition.

Table 12

Students' ratings of the chart and its effect on error recognition

Extract 1: Somewhat. It is hard to fill it out when I don't know what each error falls under. Extract 2: The chart is the primary resource I use to rewrite my first chart. By using the chart I am able to correct my own draft with the correct direction of the teacher. I am not receiving the full answer but just enough so that I can learn what I did incorrect and then fix my own mistakes. Extract 3: Yes, it shows where I need improvement.

Extract 4: Yes, it helps me keep track of the mistakes I have made. I also like to keep track of which case I struggle with the most.

Extract 5: Yes, it helps you identify areas of multiple errors.

Extract 6: No, counting my mistakes does not help fix them.

Extract 7: It has the potential to show a student his/her strong and weak points. I think that it definitely would have value for someone trying very hard to learn a new language.

Extract 8: Yes, because it is visual aid. 
Extract 9: The chart did not help me. I knew already what mistakes I had.

Extract 10: The chart that is based on the correction marks on my drafts helped me a lot in figuring out what mistakes I made and how to go about correcting them appropriately. Extract 11: I think the chart could be a very valuable learning tool. It has the potential to show students their strong and weak points in writing. It allows them to study harder in the areas they made mistakes. I didn't benefit from it, but I also only really made one mistake on my first draft. Extract 12: It actually is a visual guide that helps a lot, highlighting the spots I need to fix. Extract 13: It wasn't so much the chart, as it was the instructor's corrections.

Based on a summary of all student comments regarding the effectiveness of the ECJ, the following statements can be made. The chart in the ECJ helps students recognize their errors and therefore added them in writing the second draft (Extract $2 \& 10$ ). Because there is a clear overview of grammatical categories, students can refer to the chart to identify their previous mistakes and therefore avoid them in the future. The ECJ helps students keep track of the mistakes and identify multiple errors (Extracts 3, 4, \& 5) because they must physically enter the number of mistakes. By maintaining a running tally of errors, the students were more aware of the number and frequency of errors and were therefore empowered to do better on a second draft if they referred to the list of mistakes and avoided them on the second draft. Students also noted that the ECJ helped students learn by its virtue as a visual aid (Extracts 7,8,11, \& 12). Students could look at the list of grammatical categories and ask for help from the instructor on a discrete point in a certain category before moving on to a second grammatical category at the same time.

The completion of the chart in the ECJ did not appear to be equally effective for all students in the Experimental Group. Many students at the 203 level do not understand the grammatical categories into which their errors fall and are not able to identify those grammatical points as areas of difficulty. According to the comments, students benefited most from logging their errors in a chart only if the information in the chart could be corroborated and explained by 
the teacher's corrections. They needed teacher feedback in order to understand exactly what their errors were, which category they fell under, and how they could be improved.

Students were also asked to gage the benefits of using the ECJ to help them with future written assignments. In response, they acknowledged when, why, and how they can benefit from the ECJ as a learning tool. When the error correction chart was combined with teacher feedback, the students recognized and underscored the positive effect that the ECJ can have on their recognition and avoidance of mistakes in the future. The following table shows illustrative comments about the students' use of the ECJ to recognize and correct their mistakes on multiple drafts of writing assignments (Q 5).

Table 13

Students' Comments about their Future Writing

Extract 14: Yes, the more I practice those certain aspects of German.

Extract 15: I think while I may not be able to avoid all of these mistakes in the future, every time I do a second draft I am getting close to making fewer errors on my future drafts.

Extract 16: With some repetition I will be able to avoid these mistakes.

Extract 17: I typically try to learn from my mistakes on exams. Most of my errors tend to be stupid mistakes.

Extract 18: Probably will be able to avoid the plural mistakes. I still make adjective mistakes here and there.

Extract 19: I believe that I can better avoid these same mistakes in the future, but that I will inevitably make the same mistakes many times again until I have mastered the language.

Extract 20: No when taking a test it is hard to avoid.

As suggested by the above table, students recognized the usefulness of the ECJ with regard to various aspects of writing and improving their overall performance. The ECJ can be used as a guide in writing because students can go back and review typical errors that they have made in the past. Students can also use the ECJ to learn more about their mistakes, especially in highlighted grammar categories. Students expressed doubt as to whether the ECJ could help them avoid similar mistakes on tests. This view is largely attributable to the fact that students do not have the chart next to them serving as a reference tool when they are taking tests or writing a 
first draft in class. The ECJ error correction chart may also be less effective in a timed writing situation because students have multiple factors to consider, such as number of words, response to the prompt and exhibiting creativity, in a limited number of minutes. Given other factors, students may refer less to the ECJ when under a time constraint.

\section{Students' Perception of Their Own Improvement}

It was very important not only to determine whether an ECJ can help students or not, but also to look at their improvement and whether students are aware of their mistakes, the frequency of their mistakes and how they may be able to avoid them. An important aspect of the chart in the ECJ is, however, not simply that students count their mistakes, but that they also understand the nature and origin of the errors they make and that they see progress from one draft to the next. The charting of errors helped students to notice the categories with which they had the most difficulty and to examine the rules that were most challenging for them to understand. In order to $\log$ mistakes, students needed to understand the nature of their errors and the reasons for why they made them. By reflecting on these questions, students were required to examine more closely their learning processes and their behaviors while completing a formal written assignment. The table below summarizes students' comments regarding the writing of the second draft, the types of errors they made, and the source of these errors. By examining their writing practices on the second draft, students could check for themselves to see if they had made improvements from the first draft and in which categories, and if not, the reason for the lack of change. 
Table 14

Questions about the Second Draft

1. What do you think about your errors?

2. Why do you think you made them?

3. Do you understand now why your constructions have those errors?

4. Do you think you have improved from the second draft and the ECJ?

5. Can you tell me more about your motivation for future writing?

The answer to the first question provides information about students' attitudes toward mistakes and whether they were aware of them while writing. Students' responses to the question were mixed and highlighted below.

Table 15

Students Comments on Their Errors

Extract 21: I made quite a few, and would like to make less.

Extract 22: I made less than I thought I would.

Extract 23: I have made more spelling errors than anything else. This makes me feel like I just need to spend more time studying. The rest of my errors I feel as though they are general simple mistakes that I can fix by practicing writing German repeatedly.

Extract 24: There were more than what I should have done.

Extract 25: I made some foolish mistakes.

Extract 26: I feel like my errors were moderate errors that can be fixed with practice.

Extract 27: They are spread out over multiple areas of language.

Extract 28: My errors were careless but easily correctible.

Extract 29: I think my errors were mainly the same throughout the whole paragraph. I seemed to choose the wrong words and forget the endings on adjectives.

Extract 30: I think I made too many errors.

As outlined in the table, students described their errors as: "simple", "foolish", "moderate", “careless", "correctible with more practice", "spread out over various grammar areas." The fact that students reflect on their errors and consider their origin through the ECJ suggests that the process of recording those errors can help them understand the nature of their mistakes. This awareness can ultimately lead to the avoidance of similar errors in the future. If students are not aware of or interested in their mistakes, there is no foundation for them to begin to improve. 
Only after they recognize something as an error, can they go about changing it. Pienemann (1989) proposes that language is teachable if the structure is taught close to the time when the student is ready to acquire it in the natural order of acquisition. Through the process of selfreflection on errors, students are taking proactive steps toward readying themselves to learn new forms. In addition, the feedback that they receive from the teacher is slightly above the level at which they made the error, and, therefore, based on the notion of comprehensible input and $i+1$ (Krashen, 1985), the error correction process is an instrumental form of scaffolding that bolsters self-directed learning on the part of the individual. Ultimately the ECJ is a form of structured input (VanPatten, 1996) based on the manner in which it fosters awareness and facilitates noticing. Students' observations about their mistakes are highlighted in the table below. Table 16 Reasons for Making Mistakes

Extract 31: There are some aspects of the language I don't understand. Extract 32: I didn't spend adequate time memorizing some of the words and locations.

Extract 33: I believe I made most of my errors because I have not practiced using those words I messed up enough. Extract 34: Some were me forgetting gender and others were bad sentence order. Extract 35: I made one adjective ending mistake that I shouldn't have. The other mistakes were due to it being a while since I used the Nominative case. I think with some practice I can get the grammar right.

Extract 36: I simply haven't used the words enough to know how they are supposed to be used.

Extract 37: I was lazy and I was rushing.

Extract 38: I think I made those errors because I do not fully understand when to change the endings on adjectives. Also I think I get confused when one word sounds better in a sentence because I always choose the word I know best.

Extract 39: I think I made them because I don't have as big vocabulary as I would like.

Extract 40: I didn't study enough.

As outlined in the table, the most frequent reasons students gave for making mistakes were based on the incomprehension of new structures. They also commented that they did not have enough time to practice (Extracts 31,33, 35, \& 38) and were not able to memorize new structures (Extracts $32 \& 34$ ), or become familiar with new structures (Extracts $36 \& 39$ ). Students did 
admit, however, that they might have been undermotivated to study or were interested in finishing the assignment as soon as possible (Extracts $37 \& 40)$. These comments reveal a high degree of honesty in self-examination and demonstrate that students understand that the failure to take a proactive role in their learning can have a negative impact on their performance. Students also commented on the short length of time they had been learning the language as a reason for struggling with its forms (Extracts $36 \& 39$ ). Some of the new structures were usually presented a week or two weeks prior to the essay, and even if the students practiced and had several homework assignments after each class period, they still were not always able to familiarize themselves with the new rules. As a result, they were not always ready to produce some of the structures, such as adjective endings or the simple past tense of the irregular verbs, because they did not internalize the new rule or experienced interference from their L1 in trying to produce the forms. Due to the lack of familiarity with new structures, many students overgeneralized or applied incorrect rules. Ultimately, the results of the qualitative survey indicate that students believed their performance improved from the first to the second draft because they understood better structures that were less familiar to them previously.

Many students with a better understanding of grammatical forms may have made mistakes on forms even if they knew how to write them correctly. These mistakes were not based on a lack of understanding, but instead on other issues like time constraints or a sense of anxiety during the assessment process. Regardless of the reasons for their errors, all students believed they improved from first to second drafts based on the ECJ and therefore received a better grade (Extract $43 \& 49$ ), made fewer errors (Extracts 42, 47, 48, \& 50), and gained a better understanding of the principles they had been learning (Extracts 41, 45, \& 46). 
Table 17

Students' Improvement

Extract 41: I have improved from the second draft. Not only was I able to correct most of my mistakes, I was able to better understand why I made the mistakes I did.

Extract 42: Yes, I was able to easily correct the mistake I made on the first draft.

Extract 43: Yes. I managed to improve my grade 10 points

Extract 44: I did improve slightly but not much. I didn't understand some of my mistakes so I wasn't sure how to fix

them.

Extract 45: Yes, I have. I better understand it now.

Extract 46: Yes, I have. I better understand my story and was able to write better.

Extract 47: Yes, there were far fewer errors.

Extract 48: Yes, it shows if I was able to correct myself.

Extract 49: I got a better grade.

Extract 50: It allowed me to see and correct mistakes.

Students showed a very positive attitude toward the ECJ because, as they say, it helped them to self-correct errors based on the clearly structured and precise components of the ECJ. Due to insufficient linguistic knowledge, however, some students did have issues correcting their mistakes, and neither the second draft nor the ECJ could help them. Ultimately, it is clear that the knowledge of linguistic structures is the first factor that can help students improve their writing; the second draft and the ECJ just facilitate the process of improvement.

\section{Students' motivation toward writing}

In order to better understand how students have benefited from the whole project, in particular from the ECJ, and to better understand what they were looking at while writing their future assignments, they were asked to state whether coded correction could motivate them and to name other factors that might aid them in their future writing. The first question was among other questions that students received after the first draft (Q 1), and the most frequent answers are summarized in the table below: 
Table 18

Students' Comments on Coded Feedback and their Link to Motivation

Extract 51: It will hopefully help me make fewer mistakes.

Extract 52: I find that this type of correction feedback truly helps me feel confident in my writing abilities and in turn makes me more motivated to try writing in German again and again.

Extract 53: Yes, it shows what I need to improve.

Extract 54: Yes, it helps to focus attention on weakest areas.

Extract 55: Yes, I think if you try to get a smaller number of mistakes each time you have a IPA you will do better.

Extract 56: Yes, I like this type of feedback, I think it is helpful and motivate because it outlines all the mistakes

clearly in a chart.

The comments demonstrate that the students have had a very positive experience in general with the ECJ, and in general helped their motivation to write. They made fewer mistakes (Extract 51 $\& 55$ ) because they were able to focus on each individual grammatical category and to go back to explicit instructions on the certain category applying their knowledge and adjusting it to new constructions. They also had more time to correct their mistakes and to learn from the focus on rules instead of just rewriting the first draft with the correct answers provided without explanation. All of these factors ultimately made students feel more confident and empowered in their learning. The acquisition of new rules and exceptions to those rules helped students to feel more confident (Extract 52). Coded feedback drew their attention to their mistakes, and the opportunity to correct the mistakes by themselves motivated them to study and receive a better grade on the second draft. Students benefited not only from improvement on the second draft; the knowledge they gained about error correction would help them in the future because they know how to identify their weaknesses (Extracts 53, 54, \& 56).

The survey administered after the second draft also contained questions that were devised to gain more information about students' motivation in regard to future writing assignments. 
Students were asked to comment on the ECJ and how it affected their motivation to write. The students' answers are presented in the Table 19.

Table 19

Students' Motivation

Extract 57: I need to use better word order and sentence structures.

Extract 58: I need to study sentence structure more to make fewer mistakes.

Extract 59: I really want to improve my writing skills. I know it will take a long time, since I am not constantly

practicing. I want to make the best out of every opportunity to better my writing capabilities.

Extract 60: I need to focus on endings and word order.

Extract 61: The more practice I get, I will be better at writing.

Extract 62: I want to write an essay with no errors.

Extract 63: I would like to try to use the right words in the right order.

Extract 64: My motivation is to get good grades and not look stupid in the essays.

Extract 65: Writing in German is easier to me than speaking so I want to be perfect in it.

Extract 66: I really want to be fluent so I can live in Germany in the future so it is important that I get better and do well in the writing.

The responses indicate that there are different reasons why students' were interested in improving their writing, but in general, their motivations can be divided into two categories:

extrinsic and intrinsic. Students' answers referring to extrinsic motivation included the desire for good grades (Extraxct 64). Students are very interested in improving their grades because they are aware of the impact they may have on their future life and job search. The extrinsic motivation of good grades was also intertwined with the instrinsic motivation to move to Germany for work and to live in Germany (Extract 66). Another intrinsic motivation was the desire to improve language skills such as different grammar structures (Extract 57, 58, 59, \& 63), because students were interested in language itself and the differences and similarities between their L1 and L2. Again, this motivation was intermingled with the instrinsic motivation to better understand and communicate with Germans. Ultimately, regardless of their intrinsic or extrinsic 
source of their motivation, many students wanted to continue learning and working on their writing out of a desire to improve their linguistic proficiency (Extract $62 \& 65)$.

\section{Evaluation of Student Performance Based on the ECJ}

Students' perceptions of improvement can vary greatly from actual improvement in their performance. In order to determine if the ECJ had an effect on grammatical accuracy, the scores of students in the Experimental Group who filled out the ECJ and those in Control Group I and Control Group II were compared. We also wanted to see if there was a statistically significant improvement, so we looked for average and mode in the range of 0 to 24 because students could receive 24 points in the category of Accuracy on the rubric. The accuracy measurement was based only on the first draft of each of the three essays in order to examine writing samples that had not been rewritten or aided by the comments from the instructor. The scores that students received on each of the three essays are presented below.

Table 20

Descriptive Statistics about the First, Second and Third Essay

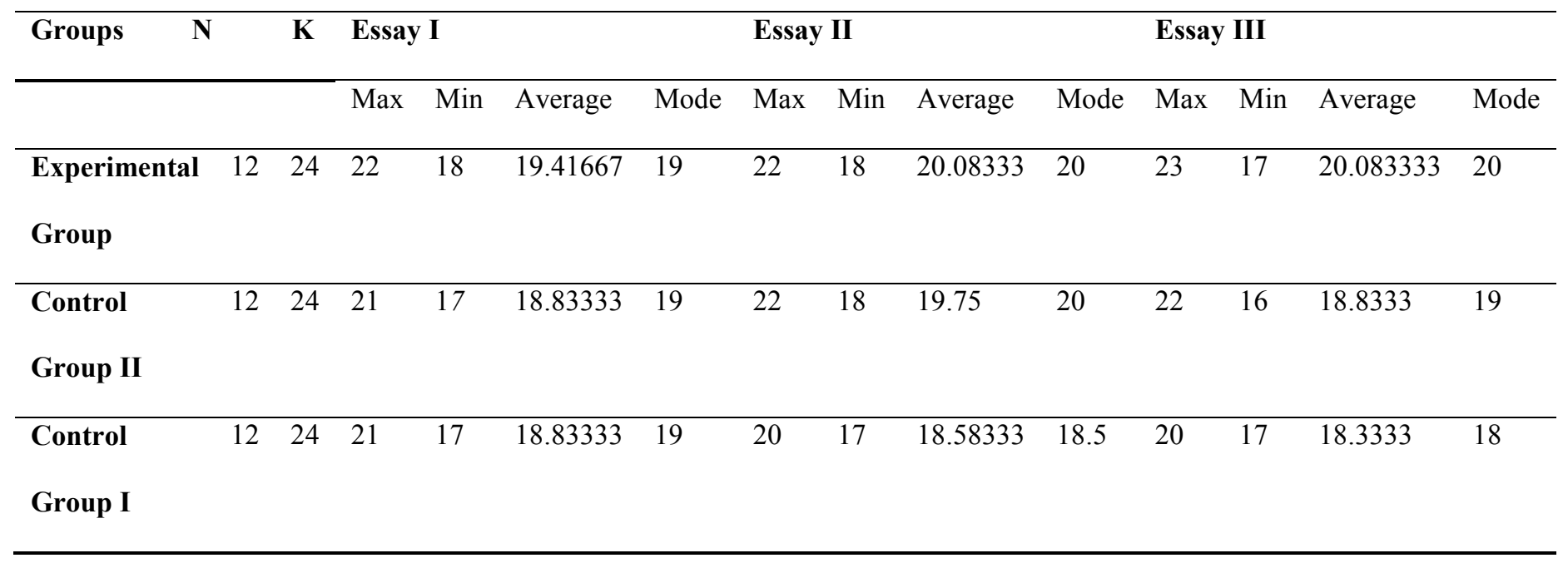


As we can see, all three groups started with almost the same average score; the Experimental Group did, however, begin with a slightly better average score. This higher score can attest to the fact that those students who chose to participate in the Experimental Group were more highly motivated or engaged in their own learning, which might also suggest that they were more successful in their language courses in general. On the second essay, the average score of the Experimental Group rose from 19.41667 to 20.08333 . The average score of Control Group II rose from 18.83333 to 19.75 . In summary, the Experimental Group improved by 0.67 , and the Control Group II improved by 0.91 . Although the end score of Control Group II is lower by 0.3 than that of the Experimental Group, the improvement of the Experimental Group was 0.25 less than the improvement of Control Group II between the two essays, which suggests that the improvement in the Experimental Group was not significant compared to Control Group II. This implies that the use of the ECJ did not help students in the Experimental Group to improve their scores in a way that was significantly better than the strategies used by Control Group II.

The average score of participants in Control Group I dropped from 18.83333 to 18.58333 . This could, in part, be attributable to the fact that students in this group received only direct feedback, although other factors may have also come into play, such as simply copying the form provided to them without learning how to improve performance (Ferris, 2003; Ferris \& Roberts, 2001; Lalande, 1982). Another factor refers to motivation, which as Guénette (2007) argues, can improve if students are provided with appropriate feedback given at the right time and at the right context. The direct feedback given to Control Group I may not have supported students' motivation enough to lead to improvement. Ultimately, it is clear that students show much more improvement if they receive coded rather than direct feedback because they have to correct their 
mistakes by themselves. Self-correction played a key factor in students' improvement from one draft to the next. The combination of coded feedback and the ECJ, however, seems to have a better long-term effect. The participants in the Experimental Group had the same average score after the second and third essay (20.083333), whereas the average score of the participants in Control Group II dropped from 19.75 to 18.8333 from the second to the third. The participants in Control Group I also showed a slightly decreased average score (from 18.58333 to 18.3333).

At the end of the study, the participants in the Experimental Group had a better average final course grade than the participants in any other group. Before we look at the final exam and see how all three groups performed at the end of the course, we can conclude that in the first three essays the Experimental Group showed an increase in performance, but Control Group II and Control Group I showed oscillations in their performance. The results of the average score on the essay of the final exam show an unexpected decline in Experimental Group. This can be explained in terms of other factors, such as the fact that all three IPAs essays were written were worth $30 \%$ whereas the final exam was worth only $20 \%$. As a result, each IPA essay was worth $1 / 3$ of the grade whereas the essay on the final exam was only worth on $1 / 8$ eighth of the course grade. The difference in the weight of the grade suggests that student performance was affected, in part, by the extrinsic motivation, of points earned toward the overall course grade. The results of the essay on the final exam are presented below.

Table 21

Descriptive Statistics about the Final Essay

\begin{tabular}{lcccccc}
\hline & $\mathrm{N}$ & $\mathrm{K}$ & Max & Min & Average & Mode \\
\hline $\begin{array}{l}\text { Experimental } \\
\text { Group }\end{array}$ & 12 & 24 & 21 & 15 & 19.16667 & 20 \\
\hline $\begin{array}{l}\text { Control } \\
\text { Group II }\end{array}$ & 12 & 24 & 22 & 18 & 19.66667 & 20 \\
\hline
\end{tabular}


Control

Group I

12

24

20

17

18.75

19

As we can see, the Experimental Group went from the average score of 20.083333 on the third essay to 19.16667 on the final essay. The participants in both control groups scored much higher on the final essay than on the third essay. The participants in Control Group II experienced a score increase, from 18.8333 to 19.66667 , and the scores of Control Group I went up from 18.3333 to 18.75 . It seems that both control groups were motivated by a better final grade than the Experimental Group because they knew that the grade on the final exam could slightly affect their final grade since their grades on the IPA were lower and the participants in the Experimental Group already knew what grade to expect. Their stakes were, therefore, not as high on the final as on the other essays. The improvement of the Experimental Group throughout the whole semester is presented in the histogram below.

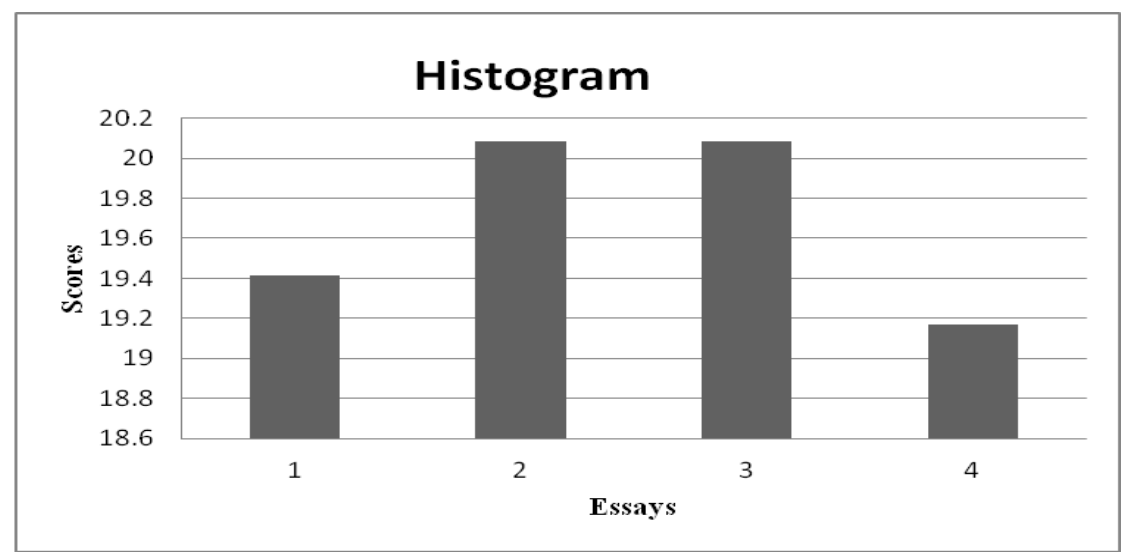

Figure 1. Histogram of improvement of the experimental group.

This histogram refers to the performance of the Experimental Group throughout the IPAs and the final essay on the final exam. It is significant that students showed a better performance on the second and the third essay based on the ECJ and coded feedback compared to the direct feedback, 
but on the final essay they showed a decline, which was likely attributable to the fact that they did not need a high grade on the final because their IPA essays were better.

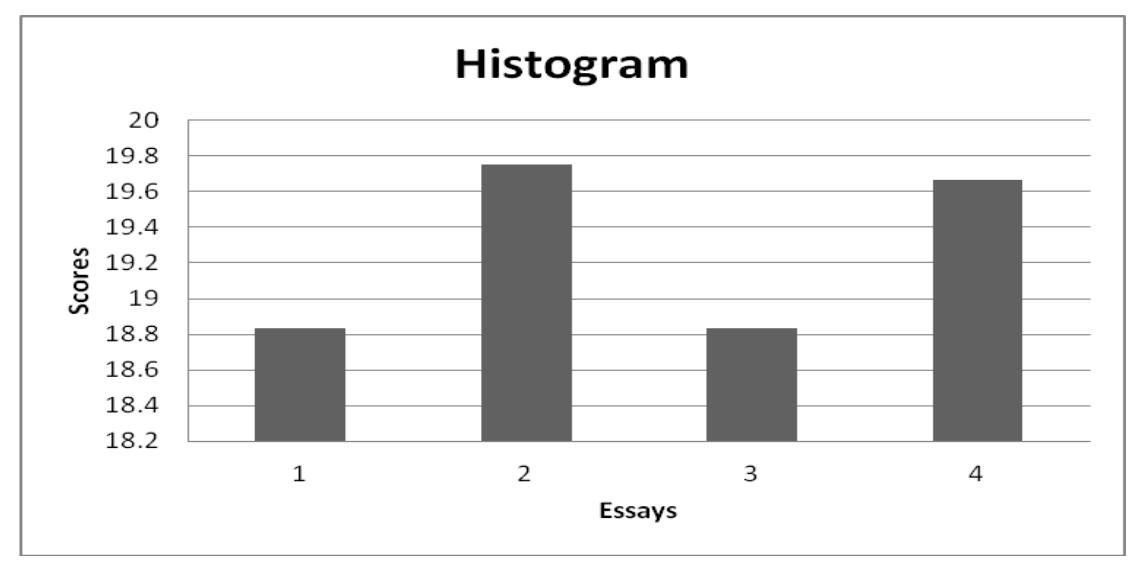

Figure 2. Histogram of improvement of control group II.

This histogram shows the writing performance of Control Group II which was able to perform very well on the second and the final essay, but very poorly on the third essay.

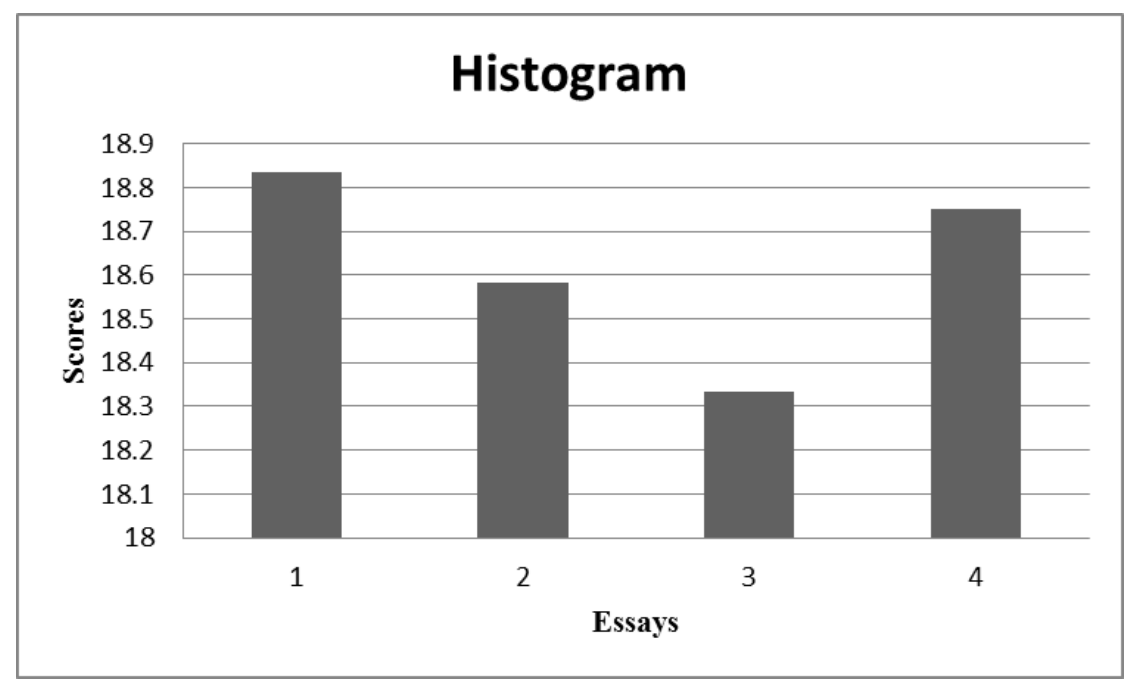

Figure 3. Histogram of improvement of control group I.

This histogram shows that Control Group I started with significantly good scores, but throughout the semester, they may have lost motivation, or the provided feedback was not appropriate for them. 
According to the histograms, the Experimental Group had the best average score on the third essay. The participants in Control Group I had the worst score on the third essay. The results show a common oscillating trend. Future research studies may show if the Experimental Group would have scored better on the last essay if it had been a fourth formal essay and not an essay on a final exam. In the last part of results, we will focus on individual mistakes so we can see how individual students improved throughout the semester.

\section{Sample of Students' Improvement on All Essays}

In order to see if the participants in all groups improved throughout the semester in grammatical structures, such as verb tense, gender and case, a sample of 14 students was collected. All students were from the same class, and as such, they were given the same instructions in class, they wrote their essays at the same time, they had to bring the second draft on the same day, and they all identified articles as a primary grammatical weakness. There are six representatives from the Experimental Group, four from Control Group II, and four from Control Group I. We used this grouping of students to control other variables such as learner, situational, and methodological variables. Students in the Experimental Group showed a positive attitude toward correction and feedback and wanted to do additional assignments in order to improve and use teacher's feedback as a good source for correction and improvement. There were six students who wanted to do the survey. Other students only wanted to write essays; these were randomly divided into two different groups, Control Group II which received coded feedback, and Control Group I which received direct feedback (all mistakes were corrected, and they only rewrote the first essay). There were several grammatical categories in which the participants were asked to correct their mistakes, but the most important categories were: verb 
tense (VT), gender (G), and case (C). Verb tense was very important because students had the opportunity to learn more about other tenses in German in addition to present tense and were asked to apply their knowledge on each of the essays. The results are presented below, and the names of the participants are coded in order to avoid the inappropriate use of names. Only initials were used, and the results are presented for each of the three groups on all three essays on both drafts.

Table 22

Sample of Students' Improvement

\begin{tabular}{|c|c|c|c|c|c|c|c|c|c|c|c|c|c|c|}
\hline & \multicolumn{6}{|c|}{ Experimental Group } & \multicolumn{4}{|c|}{ Control Group II } & \multicolumn{4}{|c|}{ Control Group I } \\
\hline & \multicolumn{14}{|c|}{ Essay I (first draft) } \\
\hline & B.G. & D.C. & B.M. & $J . R$. & $J . S$ & A.C. & J.R. & B.B & L.L. & A.W & G.S. & B.T. & V.T. & B.H. \\
\hline VT & 5 & 0 & 0 & 0 & 0 & 0 & 0 & 0 & 2 & 1 & 2 & 0 & 0 & 0 \\
\hline $\mathrm{G}$ & 4 & 2 & 0 & 0 & 0 & 2 & 1 & 2 & 2 & 3 & 2 & 5 & 2 & 4 \\
\hline $\mathrm{C}$ & 3 & 0 & 0 & 1 & 2 & 2 & 4 & 2 & 2 & 3 & 1 & 1 & 2 & 4 \\
\hline & \multicolumn{14}{|c|}{ Essay I (second draft) } \\
\hline VT & 0 & 0 & 0 & 0 & 0 & 0 & 0 & 0 & 0 & 0 & 1 & 0 & 0 & 0 \\
\hline $\mathrm{G}$ & 2 & 1 & 0 & 0 & 0 & 0 & 0 & 0 & 2 & 1 & 1 & 3 & 0 & 2 \\
\hline $\mathrm{C}$ & 1 & 0 & 0 & 0 & 0 & 0 & 1 & 0 & 0 & 1 & 0 & 0 & 0 & 2 \\
\hline & \multicolumn{14}{|c|}{ Essay II (first draft) } \\
\hline VT & 6 & 3 & 0 & 0 & 0 & 0 & 7 & 2 & 2 & 6 & 4 & 7 & 3 & 5 \\
\hline G & 3 & 1 & 2 & 0 & 1 & 2 & 3 & 4 & 0 & 2 & 1 & 4 & 1 & 1 \\
\hline $\mathrm{C}$ & 3 & 2 & 2 & 0 & 1 & 2 & 8 & 2 & 4 & 3 & 2 & 4 & 1 & 1 \\
\hline & \multicolumn{14}{|c|}{ Essay II (second draft) } \\
\hline VT & 2 & 1 & 0 & 0 & 0 & 0 & 4 & 0 & 0 & 2 & 4 & 3 & 2 & 2 \\
\hline G & 2 & 2 & 0 & 0 & 1 & 0 & 0 & 1 & 0 & 0 & 1 & 2 & 0 & 0 \\
\hline $\mathrm{C}$ & 0 & 2 & 0 & 0 & 0 & 0 & 5 & 1 & 1 & 1 & 2 & 2 & 0 & 0 \\
\hline & \multicolumn{14}{|c|}{ Essay III (first draft) } \\
\hline VT & 0 & 2 & 0 & 0 & 0 & 1 & 3 & 2 & 1 & 2 & 1 & 1 & 1 & 4 \\
\hline $\mathrm{G}$ & 0 & 3 & 0 & 4 & 1 & 0 & 3 & 1 & 2 & 2 & 0 & 1 & 2 & 2 \\
\hline $\mathrm{C}$ & 0 & 0 & 1 & 0 & 0 & 2 & 3 & 1 & 3 & 0 & 0 & 1 & 3 & 2 \\
\hline & \multicolumn{14}{|c|}{ Essay III (second draft) } \\
\hline VT & 0 & 1 & 0 & 0 & 0 & 0 & 1 & 0 & 0 & 0 & 1 & 0 & 0 & 1 \\
\hline $\bar{G}$ & 0 & 0 & 0 & 1 & 0 & 0 & 3 & 0 & 0 & 0 & 0 & 0 & 0 & 0 \\
\hline $\mathrm{C}$ & 0 & 0 & 0 & 0 & 0 & 1 & 3 & 0 & 2 & 0 & 0 & 0 & 0 & 0 \\
\hline
\end{tabular}

Looking at students' awareness of mistakes in certain grammatical structures, it is clear that students in the Experimental Group and both control groups improved from the first to the 
second drafts of essays, but they still made a considerable number of errors on the second draft. The data suggest, however, that the participants in the Experimental Group showed the most improvement and that the ECJ may have helped them to become aware of their mistakes in the category of verb tense. As explained above, the participants in the Experimental Group had the opportunity to track their mistakes, to count them, and to focus on certain categories while correcting mistakes, whereas other groups did not focus that much on their errors. Instead, they corrected mistakes or rewrote the first essay without questioning why they made the errors and providing in-depth explanations about their mistakes.

On the first essay, participants in the Experimental Group and Control Group II were able to correct all mistakes, although one participant (G.S.) in Control Group II repeated one of the mistakes. The mistakes in the category of gender and case were still a source of difficulty for students in all groups on all three essays, especially in Control Group I. Because students had just learned the past simple before writing the second essay, it is reasonable to expect more mistakes in the category of verb tense on that assignment. All three groups appear to have benefited from the feedback they received, but the participants in the Experimental Group made significantly fewer mistakes than the participants in the control groups. They were also able to improve more than the participants in the control groups because they had learned some of strategies they could use in their future writing assignments, such as keeping track of mistakes, becoming aware of improvement, and having a clear overview of grammatical categories they still have to work on.

Looking at the individual participants, it is also clear that participants in the Experimental Group were able to correct their mistakes on the second draft of the third essay in all verb tenses 
although they were focusing on the future tense. Nevertheless, some of the participants still made mistakes, albeit fewer ones than on the first draft, in gender and case (J.R., D.C.). The participants in Control Group II were likewise able to correct their mistakes in the category of verb tense because they received the coded feedback which helped them better understand the future tense. They did not, however, correct their mistakes in the category of gender and case. Coded feedback did not help them as much as direct feedback helped the participants in Control Group I. Ultimately, it appears that the reflective process required by the ECJ helped students improve in individual categories and in overall performance throughout the course of the semester.

\section{Chapter 5: Conclusion}

The main goal of this thesis was to determine whether an ECJ can help students become more aware of the mistakes they make and thereby improve their writing through a series of drafts and on future writing assignments. It also sought to examine the effect of error correction on students' motivation to write and on the role of the ECJ in giving students a sense of empowerment in their own learning. A second vital aspect of this study was to provide teachers with a new perspective on error correction in order to provide them with new strategies to employ in the teaching of writing. The research questions were: 1) Does the ECJ improve the ability of students to avoid common errors in written communication? 2) Can students perceive an improvement when use an ECJ as a learning tool? 3) Do students perceive improved motivation toward writing? The results of the study reveal a number of overarching trends among the students who participated. Both qualitative and quantitative data show that the ECJ is a good learning tool for students who are ready to correct their mistakes and who understand 
how to use a chart through which they analyze their errors. In most cases they are able to avoid making the same mistakes on the second draft of an essay, and they also show improvement from one essay to the next essay. While the differences in performance were not always significant between the Experimental Group and the Control Groups, students gained benefits beyond accuracy alone, such as increased motivation and heightened awareness of their areas of weakness. It is clear that students in the Experimental Group became more aware of their mistakes using the ECJ, and they were motivated to improve their skills based on the sense of empowerment over their own learning.

In response to the first question about the improvement of students using the ECJ, the data have suggested a variety of answers. For some students it was very helpful to rely on the logging of errors and journaling about them because it enabled them to approach their weaknesses in a new and systematic way. The ECJ helped them to go about the drafting process in a more productive manner by identifying and tracking their errors and avoiding those errors on subsequent drafts. By using the ECJ, students also improved significantly in their writing overall and in particular especially in certain individual categories, such as verb tense, gender, and case.

While many students appreciated the Error Correction Journal and the greater insight into their learning that it brought to them, some of the students did not see the positive side of the chart because, while they counted errors, they did not reflect on them. As Krashen (1982) argues in his Order Hypothesis, it is clear that recording errors is not enough to bring about significant improvement in writing. Students also have to consider the source of the errors, why they made them, and how to avoid making them in the future. In short, the ECJ helps develop a more sophisticated monitoring apparatus, which Krashen argues, is necessary for developing linguistic 
competence and for making comprehensible naturally acquired speech. The ECJ enables learners to focus on correctness, to think about the form on the second draft, to look at different grammatical categories, and to check the number of mistakes in a certain category has decreased over time. An important aspect of this reflective process is that students examine and understand the rules governing the linguistic structures they used so that they can employ the correct forms in the future; coded feedback is not as effective in helping students avoid errors because it only draws their attention to an error in grammatical category, but not to a rule.

Comparing the results of the participants in the Experimental Group with those in Control Groups I and II, it is clear that the improvement of the Experimental Group was not significant compared with Control Group II on the first essay, but compared with the improvement of Control Group I on all three essays, it was much greater. The Experimental Group had the best average score on all drafts of prepared writing but not on the final essay of the final exam. The participants in the Experimental Group responded best to self-monitoring in the form of the ECJ along with the guidance of the instructor. Based on the results of Control Group I, it is apparent that direct feedback only is not enough for students to improve their writing skills because they do not have to reflect on the corrected mistakes; they simple copy the corrected speech into the new draft. This observation was also made by Chandler (2003) who discovered "that if students did not revise their writing based on feedback about errors, having teachers mark errors was equivalent to giving no error feedback" (p. 288).

The results of this study suggest that the best way to help students improve their writing skills is to provide them with the coded corrections because only then students are able to notice their mistakes, count them and gain deeper insight about the nature of the errors. Fotos (1993) 
and Schmidt (1994) argue that coded feedback is a type of consciousness raising. It raises learners' awareness about aspects of the language they are learning; in this case, German that might otherwise escape their attention while engaging in the communication. The ECJ, however, can also help students correct their mistakes by themselves. In particular, students made fewer mistakes on the second draft in the category of verb tense in comparison to the control groups, although some verb tenses were new for the participants. The ECJ helped them to practice the correct verb forms and gain clearer overview of verb tense. Through repetition, almost all participants in all groups improved their language accuracy, but the participants in the Experimental Group had a clear summary of their mistakes and were able to keep track of their own improvement. Ultimately they still made mistakes after the second draft of the third essay, but in comparison to the control groups, the errors they made did not impede communication or the meaning of the message.

Despite all of the insights that this study provided into the nature of error correction among foreign language students, it still had some shortcomings. While the analysis clearly showed many interesting aspects regarding the influence of the ECJ on the student perception of their errors, following 14 different categories of errors was too extensive. For future studies, it would be more constructive to focus on one or two grammatical areas as Bitchener and Knoch (2009) did because, as they stated, a 'single corrective feedback' is more effective in helping learner improve by narrowing their focus and ensuring that significant has occurred prior to moving to the next category. Another limitation of the study was the timeframe, in particular with regard to the first research question. The study lasted four months but would have produced more statistically results if it had been longer, e.g., throughout two semesters. In a future 
iteration of the study, it would be imperative to conduct the writing of three essays over a longer period of time and to replace the final essay with another essay not contained on the final exam. This assignment would serve as a true post-test to help show whether the ECJ can help students improve over more extensive period of time. The timeframe between essays should be longer in order to determine whether an ECJ has a long-term impact on writing performance and whether students can really benefit from using this learning tool.

Regarding the second question about students' perception of improvement while using the ECJ, the survey results suggest that students are more aware of the reasons why they make mistakes based on their use of the ECJ. They attribute these mistakes to issues such as an insufficient understanding or practice of new structures, the inability to memorize new structures, and an insufficient familiarity with new structures. This observation is logical, given that the participants had learned some of the structures only a short time prior to having to use them. One must also take into consideration the fact that students had German class only three times a week, each class lasting only 50 minutes, and that many students were not exposed to the German language outside of the classroom. Although students did not have enough time to correct their errors in the class, they were given enough time to correct the first draft at home. However, their background knowledge was still evolving as they began applying new structures. Students also stated that the ECJ provided them with more confidence because it showed them their weakest areas through the practice and repetition of structures. As Sheen (2007) has shown, meta-linguistic comments are very important for improvement. The chart that students were asked to fill out after each draft helped them improve their writing because they engaged in this metalinguistic process and identified the mistakes they made. By doing so they were able to 
recognize their strong and weak points in writing. It also allowed them to focus on their weakest areas.

In response to the third question about students' motivation toward writing, the participants showed both extrinsic and intrinsic motivations for writing, as was expected. Students were motivated to practice more, to improve their mistakes, to write fluently, to expand their vocabulary, and to get a better grade on the future assignments based on the ECJ because it made them feel empowered. The ECJ helped students to identify the categories in which they still needed to improve (sentence structure, word order, adjective endings), and it helped them to avoid making the same mistakes on subsequent assignments. It also showed them an important strategy, self-correction and reflection, that will help them improve their future writing in both their native and foreign languages. The positive ramifications of reflection and motivation are indeed the most important findings of this study. While the difference in scores on accuracy were not always significant, students in the Experimental Group revealed in both quantitative and qualitative measures that they perceived a greater understanding of their learning and therefore were more motivated to engage in the learning process.

This study also has practical ramifications for teachers interested in using a different form of correction in their courses. The findings provide important insights into learning processes that relate to other areas of educational research, such as the effect of increased awareness on the motivation to learn outside of the classroom. Through the use of the ECJ, students may become more aware of their language learning and may better recognize and avoid errors. They will also become more aware of the types of errors they usually make, and they may be ready to correct themselves with some practice. 
Using the ECJ is important because it empowers learners and helps them become more independent. Even if it does not help them correct all of their errors or significantly improve their weaknesses; it teaches them to reflect on their learning and take charge of it. This is not only an important academic skill that can be applied to other areas outside of foreign language learning, but it is also a necessary life skill that students can employ beyond the classroom. 


\section{References}

Aljaafreh, A., \& Lantolf, J. (1994). Negative feedback as regulation and second language learning in the zone of proximal development. Modern Language Journal, 78, 465-483.

Andrews, S. (2007). Teacher Language Awareness. Cambridge: Cambridge University Press.

Ashwell, T. (2000). Patterns of teacher response to student writing in a multiple-draft composition classroom: Is content feedback followed by form feedback the best method? Journal of Second Language Writing, 9, 227-257.

Barjesteh, H., Vaseghi, R. (2012). Critical thinking: A strategy in developing English reading comprehension performance. Sheikhbahaee EFL Journal, 2, 21-34.

Bitchener,S., \& Knoch,U. (2009). The contribution of written corrective feedback to language development: A ten month investigation, Applied Linguistics, 31, 193-214.

Brookes, A., \& Grundy, P. (1990). Writing for study purposes: A teacher's guide to developing individual writing skills. Cambridge: Cambridge University Press.

Brooks, L., \& Swain, M. (2009). Languaiging in collaborative writing: Creation of and response to expertise. In A. Mackey \& C. Polio (Eds.), Multiple perspectives on interaction: Second language research in honor of Susan M., 58-59, New York, NY: Routledge.

Brown, G. (2000). Changing views of language in applied linguistics. In H. Trappes-Lomax (Ed.), Change and continuity in applied linguistics (pp. 1-14). Clevedon: Multinlingual Matters. 
Chandler, J. (2003). The efficacy of various kinds of error feedback for improvement in the accuracy and fluency of L2 student writing. Journal of Second Language Writing, 12, 267-296.

Chomsky, N. (1959). A review of B. F. Skinner's Verbal behavior. In L. A. Jakobovits \& M. S. Miron (Eds.), Readings in the psychology of language. (pp. 142-143). Prantce-Hall.

Chomsky, N. (1965). Aspects of the theory of syntax. Cambridge: MIT Press.

Diab, R. (2005). EFL university students' preferences for error correction and teacher feedback in writing. TESL Reporter, 38, 27-51.

Edge,J. 1989. Mistakes and correction. Longman Keys to Language Teaching. Harlow: Longman.

Ellis, R. (2005). Introduction: Investigating form-focused instruction. Language Learning, 51, 146.

Ellis, R., Loewen, S., \& Erlam, R. (2006). Implicit and explicit corrective feedback and the acquisition of L2 grammar. Studies in Second Language Acquisition, 28, 339-368.

Ellis, R. (2009). A typology of written corrective feedback types. ELT Journal, 63, 97-107.

Falhasiri,M., Tarakoli, M., Hasiri, F., Mohammadzadeh,A. (2011). The effectiveness of explicit and implicit corrective feedback on interlingual and intralingual errors: A case of error analysis of students' compositions. English Language Teaching, 4, 251-264.

Fathman, A., \& Whalley, E. (1990). Teacher response to student writing: Focus on form versus content. In B. Kroll (Ed.), Second language writing: Research insights for the classroom (pp.178-190). Cambridge: Cambridge University Press. 
Ferris, D., \& Roberts, B. (2001). Error feedback in L2 writing classes. How explicit does it need to be? Journal of Second Language Writing, 10, 161-184.

Ferris, D. R. (2006). Does error feedback help student writers? New evidence on the short- and long-term effects of written error correction. In K. Hyland \& F. Hyland (Eds.), Feedback in second language writing: Contexts and issues (pp. 81-104). Cambridge, UK: Cambridge University Press.

Ferris, D. (2010). Second language writing research and written corrective feedback in SLA. Studies in Second Language Acquisition, 32, 181-201.

Fotos, S. (1993). Consciousness-raising and noticing through focus on form: Grammar task performance versus formal instruction. Applied Linguistics, 14, 385-407.

Greenslade, T., \& Félix-Brasdefer,J. (2006). Error correction and learner perceptions in L2 Spanish writing. In C.A.Klee \& T.L. Face (Eds.), Selected proceedings of the $7^{\text {th }}$ conference on the Acquisition of Spanish and Portuguese as First and Second Languages (pp.185-194). Somerville, MA: Cascadilla Proceedings Project.

Greenia, G. (1992). Computers and teaching composition in a foreign language. Foreign Language Annals, 25, 33-46.

Guénette, D. (2007). Is feedback pedagogically correct? Research design issues in studies of feedback on writing. Journal of Second Language Writing, 16, 40-53.

Harmer, J. (2009). How to teach English. Pearson: Longman

Hedgcock, J., \& Lefkowitz, N. (1996). Some input on input: Two analyses of student response to expert feedback in L2 writing. Modern Language Journal, 80, 287-308. 
Homstad, T., \& Thorson, H. (1996). Writing theory and practice in the SL classroom: A selected annotated bibliography. Technical Report Series, 8, 1-42.

Kepner, C. (1991). An experiment in the relationship of types of written feedback to the development of second-language writing skills. The Modern Language Journal, 75, 305313.

Krashen, S. (1982). Principles and practices in SL acquisition. Oxford: Pergamon

Krashen, S. (1984). Writing: Research, theory, and applications. New York: Pergamon Institute.

Lalande, J. (1982). Reducing composition errors: An experiment. The Modern Language Journal, $66(2), 140-149$.

Lee, I. (2005). Error correction in the L2 writing classroom: What do students think? Tesl Canada Journal, 22, 1-16.

Leki, I. (1991). The preferences of ESL students for error-correction in college-level writing classes. Foreign Language Annals, 24, 203-218.

Lennon, P. (1991). Error: Some problems of definition and identification. Applied Linguistic, 12, 180-195.

Long, M. H. (1991). Focus on form: A design feature in language teaching methodology. In K. D. Bot, R. B. Ginsberg \& C. Kramsch (Eds.), Foreign language research in cross-cultural perspective. Amsterdam: Benjamins.

Lyster, R., Lightbrown, P. M. \& Spada, N. (1999). A response to Truscott's "What's wrong with oral grammar correction.“ Canadian Modern Language Review, 55, 546-567.

McLaughlin, B. (1987). Theories of second language learning. London: Edward Arnold. 
Nassaji, H., \& Swain, M. (2000). A Vygotskian perspective on corrective feedback: The effect of random versus negotiated help on the learning of English articles. Language Awareness, 4, 95-121.

Pienemann, M. (1984). Psychological constraints on the teachability of languages. Studies in Second Language Acquisition, 6, 186-214.

Polio, C., \& Sachs, R. (2007). Learners' uses of two types of written feedback on a L2 writing revision task. Studies in Second Language Acquisition, 29, 67-100.

Polio, C. (2012). The relevance of second language acquisition theory to the written error correction debate. Journal of Second Language Writing, 21, 375-389.

Radecki, P. M., \& Swales, J. M. (1988). ESL student reaction to written comments on their written work. System, 16, 355-365.

Schmidt, R. (1994). Deconstructing consciousness in search of useful definitions for applied linguistics. AILA Review, 11, 11-26.

Selinker, L. (1972). Interlanguage. International Review of Applied Linguistics, 10, 209-231.

Selinker, L. (1984). The current state of interlanguage studies: An attempted critical summary interlanguage. Edinburgh: Edinburgh University Press.

Semke, H. (1984). The effect of the red pen. Foreign Language Annals, 17, 195-202.

Sheen, Y. (2007). The effect of focused written corrective feedback and language aptitude on ESL learners' acquisition of articles. TESOL Quarterly, 41, 255-283.

Sheppard, K. (1992). Two feedback types: Do they make a difference? RELC Journal, 23, 103110.

Skehan, P. (1998). A cognitive approach to language learning. Oxford: Oxford University Press. 
Skinner, B. F. (1957). Verbal behavior. New York: Appleton-Century-Corfts.

Stern, H.H. (1992) Issues and Options in Language Teaching. Oxford: Oxford University Press.

Truscott, J. (1996). The case against grammar correction in L2 writing classes. Language Learning, 46 (2), 327-369.

Truscott, J., \& Hsu, A. (2008). Error correction, revision, and learning. Journal of Second Language Writing, 17, 292-305.

Van Beuningen, C. (2010). Corrective feedback in L2 writing: Theoretical perspectives, empirical insights, and future directions. International Journal of English Studies, 10 (20), $1-27$.

VanPatten, B. (1996). Input processing and grammar instruction: Theory and research. Norwood, NJ: Ablex.

Vygotsky, L. (1978). Mind and society. Cambridge, MA: Harvard University Press.

Vygotsky, L. S (1986). Thought and language. MIT Press: Cambridge, MA. 


\section{Appendix}

\section{Appendix A}

\section{A Chart of Errors in German Compositions}

The following chart should provide significant evidence about your areas of weakness in which you made the most errors on the first draft of your composition in German and analyze the nature of your errors. You will rate your grammar ability to use the certain forms in several grammar parts: verbs, nouns and articles, pronouns, adjectives, prepositions, negation, word order, conjunctions. Please look at your errors you made on the first draft and write how frequently your errors occurred on the first draft of your composition. It means that you should write the right number of your errors made in that grammar part. In each column you can find a number that is related to the whole amount of errors you made in your composition, and it helps you to categorize the frequency of your errors. Please answer all questions to the best of your ability. The last column is related to the errors on the second draft so write just the number of your errors in the certain category.

\begin{tabular}{|c|c|c|c|c|c|c|c|c|}
\hline \multirow{2}{*}{\multicolumn{9}{|c|}{ Verb Form }} \\
\hline & & & & & & & & \\
\hline Verb Tense & & & & & & & & \\
\hline $\begin{array}{l}\text { Subject-Verb } \\
\text { Agreement }\end{array}$ & & & & & & & & \\
\hline Gender & & & & & & & & \\
\hline Article & & & & & & & & \\
\hline Case & & & & & & & & \\
\hline Plural & & & & & & & & \\
\hline $\begin{array}{l}\text { Adjective } \\
\text { Ending }\end{array}$ & & & & & & & & \\
\hline Pronoun & & & & & & & & \\
\hline Negation & & & & & & & & \\
\hline Preposition & & & & & & & & \\
\hline Word Order & & & & & & & & \\
\hline Wrong Word & & & & & & & & \\
\hline Conjunctions & & & & & & & & \\
\hline $\begin{array}{l}\text { Sentence } \\
\text { Structure }\end{array}$ & & & & & & & & \\
\hline
\end{tabular}




\section{Appendix B}

\section{A Survey of Errors in German Compositions}

The following survey should provide an insight into your errors in German compositions, especially into the greatest areas of weakness in which you make the most errors. Please recall those areas answering the following questions and rating them on the scale from 0 to 5 ( 0 -never, 1-very rarely, 2-rarely, 3-occasionally, 4-frequently, 5-very frequently). Please circle the number you think the best describes your errors, and answer all of the questions to the best of your ability.

1. How often do you make errors in German compositions?

$\begin{array}{llllll}0 & 1 & 2 & 3 & 4 & 5\end{array}$

2. How often do you get a feedback?

$\begin{array}{llllll}0 & 1 & 2 & 3 & 4 & 5\end{array}$

3. How often are you satisfied with that feedback?

$\begin{array}{llllll}0 & 1 & 2 & 3 & 4 & 5\end{array}$

4. What do you think is the greatest grammar area you make the most errors? Circle just one area.
○ Verbs
○ Nouns
○ Articles
- Pronouns
○ Adjectives
○ Prepositions

5. How often do you make verb errors?

$\begin{array}{llllll}0 & 1 & 2 & 3 & 4 & 5\end{array}$

6. How often do you make noun and article errors?

$\begin{array}{llllll}0 & 1 & 2 & 3 & 4 & 5\end{array}$

7. How often do you make pronoun errors?

$\begin{array}{llllll}0 & 1 & 2 & 3 & 4 & 5\end{array}$


8. How often do you make adjective ending errors?

$\begin{array}{llllll}0 & 1 & 2 & 3 & 4 & 5\end{array}$

9. How often do you make preposition errors?

$\begin{array}{llllll}0 & 1 & 2 & 3 & 4 & 5\end{array}$

10. How often do you make negation errors?

$\begin{array}{llllll}0 & 1 & 2 & 3 & 4 & 5\end{array}$

11. Do you know the main difference between kein and nicht?

$\begin{array}{ll}\circ & \text { Yes } \\ \circ & \text { No }\end{array}$

12. How often do you make word order errors?

$\begin{array}{llllll}0 & 1 & 2 & 3 & 4 & 5\end{array}$

13. a. Is the word order in a simple declarative sentence more difficult for you than the word order in the question sentence?

○ Yes

○ No

13. b. Why do you think so?

14. How often do you make coordinating conjunction errors?

$\begin{array}{llllll}0 & 1 & 2 & 3 & 4 & 5\end{array}$

15. How often do you make subordinating conjunction errors?

$\begin{array}{llllll}0 & 1 & 2 & 3 & 4 & 5\end{array}$


16. What do you think is the best way to provide a feedback?

- Direct (errors are corrected)

- Indirect (errors are identified, but not corrected)

17. Do you think that an instructor can help students to identify the errors they make in written communication?

○ Yes

○ No

18. Do you think that an Error Correction Journal can improve the ability of students to recognize and avoid common errors in written communication?

○ Yes

○ No 
Appendix C

\section{Correction Key}

$\underline{\text { Korrekturschlüssel }}$

\begin{tabular}{|c|c|c|c|}
\hline Zeichen & Bedeutung & Übersetzung & Beispiele \\
\hline $\mathrm{AE}$ & Adjektiv-Endung & Incorrect adjective ending & $\begin{array}{l}\text { ein guter Buch: } \\
\text { ein gutes Buch }\end{array}$ \\
\hline Dpl & Pluralform im Dativ & $\begin{array}{l}\text { " } \mathrm{n} \text { " is missing from a dative } \\
\text { plural noun }\end{array}$ & $\begin{array}{l}\text { den Kinder: } \\
\text { den Kindern }\end{array}$ \\
\hline G & Genus & Incorrect gender & die Bild: das Bild \\
\hline HV & Hilfsverb & Wrong auxiliary/helping verb & $\begin{array}{l}\text { sie hat gereist: } \\
\text { sie ist gereist }\end{array}$ \\
\hline I & Idiom & Idiomatic expression & $\begin{array}{l}\text { ich bin heiss: } \\
\text { mir ist heiss }\end{array}$ \\
\hline K & Kasus & Incorrect grammatical case & $\begin{array}{l}\text { er sieht der Mann: } \\
\text { er sieht den Mann }\end{array}$ \\
\hline G-K-S & $\begin{array}{l}\text { Groß- oder } \\
\text { Kleinschreibung }\end{array}$ & $\begin{array}{l}\text { Improper capitalization/ } \\
\text { failure to capitalize where } \\
\text { needed }\end{array}$ & $\begin{array}{l}\text { das haus: das Haus } \\
\text { Wenn Ich: Wenn ich }\end{array}$ \\
\hline Konj & Konjunktion & Wrong conjunction & $\begin{array}{l}\text { Wenn ich ein Kind war } \\
\text { Als ich ein Kind war }\end{array}$ \\
\hline $\mathbf{L}$ & Logik & $\begin{array}{l}\text { Improper logic; sentence } \\
\text { does not make sense }\end{array}$ & Das Wetter spricht. \\
\hline $\mathbf{P}$ & Präposition & $\begin{array}{l}\text { Incorrect preposition or case } \\
\text { following preposition }\end{array}$ & $\begin{array}{l}\text { Ich denke um dich. } \\
\text { Ich denke an dich. } \\
\text { Ich denke an dir. } \\
\text { Ich denke an dich. }\end{array}$ \\
\hline PL & Plural & Incorrect plural form & die Bruder: die Brüder \\
\hline PR & Pronomen & Incorrect pronoun & $\begin{array}{l}\text { (der Tisch) Es ist da. } \\
\text { Er ist da. }\end{array}$ \\
\hline $\mathbf{R}$ & Rechtschreibung & Spelling error/typo & Duetsch: Deutsch \\
\hline S & $\begin{array}{l}\text { Steigerung } \\
\text { (Komparativ } \\
\text { Superlativ) }\end{array}$ & $\begin{array}{l}\text { Incorrect comparative or } \\
\text { superlative form }\end{array}$ & $\begin{array}{l}\text { Es ist viel groß. } \\
\text { Es ist viel größer } \\
\text { Das am beste Auto } \\
\text { Das beste Auto }\end{array}$ \\
\hline SD & schwache Deklination & $\begin{array}{l}\text { weak declination ("Masculine } \\
\text { N-Nouns") require "n" or "en" } \\
\text { ending in acc. dat. and } \\
\text { genitive cases }\end{array}$ & $\begin{array}{l}\text { den Student, dem Student: } \\
\text { den Studenten, dem Studenten }\end{array}$ \\
\hline SK & Satzkonstruktion & Faulty or awkward sentence & $\begin{array}{l}\text {... damit, wenn es regnet, ich } \\
\text { nicht draussen stehe. }\end{array}$ \\
\hline
\end{tabular}




\begin{tabular}{|c|c|c|c|}
\hline & & construction & $\begin{array}{l}\text { damit ich nicht draussen stehe, } \\
\text { wenn es regnet. }\end{array}$ \\
\hline ST & Stil & $\begin{array}{l}\text { Inappropriate choice of } \\
\text { expression in view of context }\end{array}$ & $\begin{array}{l}\text { Königin Elisabeth findet es } \\
\text { echt geil, dass ... } \\
\text { Königin Elisabeth ist hoch } \\
\text { erfreut darüber, dass ... }\end{array}$ \\
\hline VF & Verbform & Verb form error & $\begin{array}{l}\text { ich spiele gestern } \\
\text { ich spielte gestern } \\
\text { Ich bin gehen } \\
\text { Ich bin gegangen } \\
\text { du musst sprichst } \\
\text { du musst sprechen }\end{array}$ \\
\hline VSÜ & $\begin{array}{l}\text { Verb-Subjekt- } \\
\text { Übereinstimmung }\end{array}$ & verb-subject agreement error & $\begin{array}{l}\text { du kommen } \\
\text { du kommst }\end{array}$ \\
\hline WF & $\begin{array}{l}\text { ein Wort oder mehrere } \\
\text { Wörter fehlen }\end{array}$ & one or more words missing & $\begin{array}{l}\text { ich erinnere } \\
\text { ich erinnere mich }\end{array}$ \\
\hline WW & Wortwahl & incorrect word choice & $\begin{array}{l}\text { mit dem Auto gehen } \\
\text { mit dem Auto fahren }\end{array}$ \\
\hline WS & Wortstellung & incorrect word order & $\begin{array}{l}\text { Sie kauft ein jetzt. } \\
\text { Sie kauft jetzt ein. }\end{array}$ \\
\hline $\mathbf{x}$ & X-Beliebiges & $\begin{array}{l}\text { miscellaneous: Errors not } \\
\text { classified elsewhere; special } \\
\text { notes will be given in the } \\
\text { margins }\end{array}$ & $\begin{array}{l}\text { Wir suchen spielen. } \\
\text { Wir suchen Spiele. }\end{array}$ \\
\hline $\mathbf{Z}$ & Zeichensetzung & $\begin{array}{l}\text { incorrect or missing } \\
\text { punctuation }\end{array}$ & $\begin{array}{l}\text { Gut_ich gehe? } \\
\text { Gut, ich gehe. }\end{array}$ \\
\hline$?$ & total unverständlich & nonsensical & er aus nicht \\
\hline IS & Infinitivsatz & $\begin{array}{l}\text { incorrect use of infinitive }+z u \\
\text { constructions }\end{array}$ & $\begin{array}{l}\text { Ich habe gehen vor. } \\
\text { Ich habe vor zu gehen. }\end{array}$ \\
\hline M & Modus & incorrect use of mood & $\begin{array}{l}\text { Er würde Zeit haben. } \\
\text { Er hätte Zeit. }\end{array}$ \\
\hline VC & Voice & $\begin{array}{l}\text { incorrect use of } \\
\text { active/passive }\end{array}$ & $\begin{array}{l}\text { Es wurde ihm helfen. } \\
\text { Es wurde ihm geholfen. }\end{array}$ \\
\hline
\end{tabular}

Adapted from R. Minert 


\section{Appendix D}

\section{A Survey of Errors in German Compositions}

You have participated in the research study about error correction feedback throughout the semester. You have answered the questions about the first and the second draft of each essay. It is time now to summarize your writing skills and to how much you think you have developed them. The following survey should provide an insight into your errors in German compositions, especially into the greatest areas of weakness in which you still make the most errors. Please recall those areas answering the following questions and rating them on the scale from 0 to $5(0$ never, 1-very rarely, 2-rarely, 3-occasionally, 4-frequently, 5-very frequently). Please circle the number you think the best describes your errors, and answer all of the questions to the best of your ability.

1. How often do you still make errors in German compositions?

$\begin{array}{llllll}0 & 1 & 2 & 3 & 4 & 5\end{array}$

2. What do you think is the greatest grammar area you still make the most errors? Circle just

one area.
○ Verbs
- Nouns
- Articles
○ Pronouns
- Adjectives
o Prepositions

3. How often do you still make that type of error?
0
12
$\begin{array}{lll}2 & 3 & 4\end{array}$
5

4. Have you been satisfied with the feedback throughout the semester?

$\begin{array}{llllll}0 & 1 & 2 & 3 & 4 & 5\end{array}$

5. What do you think is the best way to provide a feedback?

- Direct (errors are corrected)

Indirect (errors are identified, but not corrected)

6. Has the instructor helped you to identify the errors you make in your written communication?

Yes No 
7. Has the Error Correction Journal helped you improve the ability to recognize and avoid common errors in written communication?

○ Yes

○ No

If yes, how? What part?

8. Has the Error Correction Journal increased your motivation to write in German in the future?

o Yes

o No

If yes, how? What part?

9. Have you improved from feedback in 203 in general?

- Yes

o No

\section{Comments:}

10. In order to improve the Error Correction Journal, I would be thankful for any additional comments and suggestion:

Thank you for your participation in the research study. 


\section{Appendix E}

\section{Deutsch 101-204: IPA Presentational Rubric}

\begin{tabular}{|c|c|c|c|c|c|c|c|c|c|c|}
\hline & Exceeds Expectations & & $\begin{array}{l}\text { Meets Expectations } \\
\text { (Strong) } \\
\end{array}$ & & \begin{tabular}{|l} 
Meets Expectations \\
(Weak) \\
\end{tabular} & & \begin{tabular}{|l|} 
Does Not Meet \\
Expectations \\
\end{tabular} & & $\begin{array}{l}\text { Performance Cannot be } \\
\text { Assessed }\end{array}$ & \\
\hline $\begin{array}{l}\text { Communication of Task } \\
\text { Adequacy of response to } \\
\text { task, effectiveness of } \\
\text { communication, content, } \\
\text { expression culturally } \\
\text { accurate meaningful. }\end{array}$ & $\begin{array}{l}\text { Student goes beyond a } \\
\text { basic response to task; } \\
\text { student uses correct } \\
\text { language in a culturally } \\
\text { meaningful way that is } \\
\text { appropriate to audience. }\end{array}$ & $\begin{array}{l}39- \\
36\end{array}$ & $\begin{array}{l}\text { Student offers a culturally } \\
\text { appropriate response to } \\
\text { task/situation; most task } \\
\text { demands met; message } \\
\text { mostly clear; student } \\
\text { demonstrates } \\
\text { understanding of } \\
\text { concepts; responds with } \\
\text { sufficient detail. }\end{array}$ & $\begin{array}{l}35- \\
31\end{array}$ & $\begin{array}{l}\text { Student offers nearly } \\
\text { acceptable response to the } \\
\text { task; some task demands } \\
\text { not adequately addressed; } \\
\text { parts of the message are } \\
\text { unclear; student reveals } \\
\text { miscomprehension; } \\
\text { response is general or } \\
\text { narrow. }\end{array}$ & $\begin{array}{l}30- \\
26\end{array}$ & $\begin{array}{l}\text { Student attempts to } \\
\text { communicate but does } \\
\text { not fulfill most task } \\
\text { demands; response to } \\
\text { task/situation is } \\
\text { inappropriate; student } \\
\text { frequently demonstrates } \\
\text { miscomprehension of } \\
\text { details; avoids using the } \\
\text { target language or resorts } \\
\text { to English } \\
\end{array}$ & $\begin{array}{l}25- \\
23\end{array}$ & $\begin{array}{l}\text { Student unable to perform } \\
\text { task. Communication } \\
\text { breaks down. }\end{array}$ & 0 \\
\hline $\begin{array}{l}\text { Language Control } \\
\text { Correct use of appropriate } \\
\text { grammatical forms, } \\
\text { register, and tense. }\end{array}$ & $\begin{array}{l}\text { Grammatical structures } \\
\text { used go beyond } \\
\text { expectations; highly } \\
\text { accurate; very few errors } \\
\text { in morphology/syntax; } \\
\text { errors do not compromise } \\
\text { meaning. }\end{array}$ & $\begin{array}{l}24- \\
22\end{array}$ & $\begin{array}{l}\text { Grammatical structures } \\
\text { used are appropriate for } \\
\text { task; good control of } \\
\text { fundamental structures; } \\
\text { some errors in } \\
\text { morphology/syntax; some } \\
\text { errors, but do not hinder } \\
\text { communication. } \\
\end{array}$ & $\begin{array}{l}21- \\
19\end{array}$ & $\begin{array}{l}\text { Grammatical structures } \\
\text { are. appropriate for task } \\
\text { but include many errors, } \\
\text { some of which impede } \\
\text { comprehensibility. } \\
\text { Frequent errors in } \\
\text { morphology/syntax. }\end{array}$ & $\begin{array}{l}18- \\
17 \\
{[1]}\end{array}$ & $\begin{array}{l}\text { Grammatical structures } \\
\text { are imappropriate for task. } \\
\text { Inadequate control of } \\
\text { basic structures; frequent } \\
\text { errors in } \\
\text { morphology/syntax. } \\
\text { Errors compromise } \\
\text { communication. } \\
\end{array}$ & $\begin{array}{l}16- \\
15 \\
{[1]}\end{array}$ & $\begin{array}{l}\text { Student unable to perform } \\
\text { task. Inaccurate use of } \\
\text { grammatical structures } \\
\text { leads to breakdown in } \\
\text { communication. Text } \\
\text { produced is } \\
\text { incomprehensible. }\end{array}$ & 0 \\
\hline $\begin{array}{l}\text { Content/Vocabulary } \\
\text { Use of new or relevant } \\
\text { vocabulary; creative } \\
\text { approach to material; } \\
\text { involvement of all } \\
\text { speakers. }\end{array}$ & $\begin{array}{l}\text { Good command of } \\
\text { customary vocabulary for } \\
\text { the level; some attempts } \\
\text { made at using known } \\
\text { words creatively or } \\
\text { employing new words not } \\
\text { yet part of the typical } \\
\text { lexicon. Excellent use of } \\
\text { dictionary demonstrating } \\
\text { appropriate word } \\
\text { selection. }\end{array}$ & $\begin{array}{l}24- \\
22 \\
{[1]}\end{array}$ & $\begin{array}{l}\text { Good command of } \\
\text { working yocabulary but } \\
\text { no experimentation with } \\
\text { new words. Vocabulary } \\
\text { is largely used correctly } \\
\text { with some minor errors } \\
\text { that do not impede } \\
\text { comprehensibility. } \\
\text { Adequate use of } \\
\text { dictionary. }\end{array}$ & $\begin{array}{l}21- \\
19\end{array}$ & $\begin{array}{l}\text { Attempts at using words } \\
\text { from working vocabulary } \\
\text { that include multiple } \\
\text { errors. Words used } \\
\text { incorrectly, or the wrong } \\
\text { word is chosen. Some } \\
\text { reliance on English. } \\
\text { Inadequate use of } \\
\text { dictionary. }\end{array}$ & $\begin{array}{l}18- \\
17 \\
{[1]}\end{array}$ & $\begin{array}{l}\text { Inadequate command of } \\
\text { working vocabulary. } \\
\text { Heavy reliance on } \\
\text { cognates. Words used } \\
\text { imcorrectly or mixed with } \\
\text { Germanized versions of } \\
\text { English words. Evidence } \\
\text { of some online translator } \\
\text { use. }\end{array}$ & $\begin{array}{l}16- \\
15 \\
\\
{[1]}\end{array}$ & $\begin{array}{l}\text { Missing or incorrectly } \\
\text { used vocabulary. Nearly } \\
\text { total reliance on English. } \\
\text { Evidence of online } \\
\text { translator use. }\end{array}$ & 0 \\
\hline $\begin{array}{l}\text { Creativity/Sentence } \\
\text { Variation } \\
\text { Experimentation with and } \\
\text { variation of sentence } \\
\text { structure. Attempts to } \\
\text { demonstrate varied word } \\
\text { order and more complex } \\
\text { sentence structure } \\
\text { including conjunctions } \\
\text { and front fields. }\end{array}$ & $\begin{array}{l}\text { Student uses a variety of } \\
\text { sentence structures, } \\
\text { which may include front } \\
\text { fields or conjunctions. } \\
\text { Structure varies from } \\
\text { sentence to sentence, and } \\
\text { sentences build upon one } \\
\text { another logically. }\end{array}$ & $\begin{array}{l}13- \\
12 \\
\\
{[\mathrm{]}]}\end{array}$ & $\begin{array}{l}\text { Some use of varied } \\
\text { sentence structure with } \\
\text { inconsistencies in word } \\
\text { order and verb placement. } \\
\text { Although some variation } \\
\text { present, most sentence } \\
\text { follow a subject-verb } \\
\text { model. }\end{array}$ & $\begin{array}{l}11- \\
10\end{array}$ & $\begin{array}{l}\text { All sentences follow the } \\
\text { same subject-verb model. } \\
\text { No attempts at variation, } \\
\text { but sentences follow in } \\
\text { logical order. }\end{array}$ & [ ] & $\begin{array}{l}\text { All sentences follow the } \\
\text { same subject-verb model } \\
\text { with some errors. No. } \\
\text { attempts at variation and } \\
\text { sentences de not. } \\
\text { necessarily followr a. } \\
\text { logical order. }\end{array}$ & $\begin{array}{l}8-7 \\
{[1]}\end{array}$ & $\begin{array}{l}\text { Evidence of online } \\
\text { translator use. Text } \\
\text { imcomprehensible. }\end{array}$ & 0 \\
\hline
\end{tabular}

Student Score:

Communication + Language Control + Content Vocabulary + Creativity/Sentence $=$ Total Score

\section{Comment:}


